\title{
REAVALIAÇÃO DA EVOLUÇÃO GEOLÓGICA EM TERRENOS PRÉ- CAMBRIANOS BRASILEIROS COM BASE EM NOVOS DADOS U-Pb SHRIMP, PARTE II: ORÓGENO ARAÇUAÍ, CINTURÃO MINEIRO E CRÁTON SÃO FRANCISCO MERIDIONAL(*)
}

\author{
LUIZ CARLOS DA SILVA', RICHARD ARMSTRONG ${ }^{2}$, CARLOS MAURÍCIO NOCE \\ MAURÍCIO ANTÔNIO CARNEIRO ${ }^{4}$, MÁRCIO PIMENTEL ${ }^{5}$, ANTONIO CARLOS PEDROSA- \\ SOARES ${ }^{3}$, CARLOS AUGUSTO LEITE', VÁLTER SALINO VIEIRA ${ }^{6}$, MÁRCIO ANTONIO DA \\ SILVA $^{6}$, VINÍCIUS JOSÉ DE CASTRO PAES ${ }^{6} \&$ JOÃO MORAES CARDOSO FILHO ${ }^{6}$
}

\begin{abstract}
REASSESSMENT OF THE GEOLOGIC EVOLUTION OF SELECTED PRECAMBRIAN TERRANES IN BRAZIL, BASED ON NEW SHRIMP U-Pb DATA, PART II: MINEIRO AND ARAÇUAÍ OROGENS AND SOUTHERN SÃO FRANCISCO CRATON This paper discusses new zircon SHRIMP (Sensitive High Resolution Ion Microprobe) U-Pb geochronological data for 19 key-exposures of several geological units exposed at the eastern border of the Southern São Francisco Craton and at the adjacent Proterozoic Mineiro and Araçuaí orogens. Samples were collected along several E-W transects, aiming at tracing the precise limit of the São Francisco Craton Archean basement, as well as assessing the extension of the successive proterozoic orogenic collages. Due to the complex geologic history and/or high grade metamorphism which most of the rock units investigated have undergone, zircon morphology and the U- $\mathrm{Pb}$ analytical data exhibit very complex patterns. These are characterized by a combination of inheritance, partial resetting and new zircon growth during high-grade metamorphism. As a consequence, very careful and detailed analyses of cathodoluminescence imagery were required to allow distinction between inheritance, newly melt-precipitated zircon and partially reset zircons, as well as between the ages of magmatic and metamorphic events. In the southeastern border of the craton 5 units yielded Archean crystallization ages ranging from $c a .3000-2700 \mathrm{Ma}$, with poorly constrained metamorphic ages ranging from $c a .2850$ to $550 \mathrm{Ma}$. The TTG gneissic complex exposed to the east and south of the Quadrilatero Ferrifero, formerly ascribed to the Archean basement, have crystallization ages from $c a .2210 \mathrm{Ma}$ to $2050 \mathrm{Ma}$, and can now be interpreted as representing pre-to syn-collisional magmatic phases of the Mineiro Belt. Metamorphic ages of $c a .2100 \mathrm{Ma}$ and $560 \mathrm{Ma}$ are also well constrained in zircon populations from these gneisses. The crystallization age of $c$ a 1740 Ma observed for an alkaline granite of the Borrachudos Suite (intrusive into the Archean basement east of the Southern Espinhaço Range) confirmed previous conventional U-Pb data for this Paleoproterozoic rift-related magmatism. One of the major basement inliers within the Araçuaí Orogen, the Caparaó charnockitic granulite, revealed magmatic crystallization age of ca. $2195 \mathrm{Ma}$. Zircons from an amphibolite of the Pocrane Complex, also a basement inlier within the Araçuaí Orogen, yielded an age of ca. $1500 \mathrm{Ma}$. Both inliers furnished well-constrained neoproterozoic metamorphic overprint at $c a .590 \mathrm{Ma}$. The subalkaline gneissic granite from the Salto da Divisa Suite yielded a magmatic crystallization age of $c a .870 \mathrm{Ma}$, close to U-Pb ages of the continental rift magmatism found in the African counterpart of the Araçuai Orogen. Four gneissic granites from the Araçuai Orogen (three of them previously interpreted as part of the Archean/Paleoproterozoic basement) were dated in the range of ca. 560-570 Ma, and were correlated to the $\gamma_{2}$ syn-collisional magmatism. Borders of some zircon grains from the older ( $\mathrm{ca}$. $570 \mathrm{Ma}$ ) dated unit (Nanuque Granite) yielded ages around $500 \mathrm{Ma}$, similar to U-Pb ages obtained from titanite, monazite and zircon in other localities from the Araçuai Orogen. This youngest ages could be related to heating effects caused by melting of country rocks and ascent of magmas formed during the collapse of the orogen.
\end{abstract}

Keywords: SHRIMP U-Pb analysis; Araçuaí and Mineiro orogens, São Francisco Craton,

Resumo Esse artigo discute os resultados de novas datações geocronológicas U-Pb SHRIMP (Sensitive High Resolution Ion Microprobe) em zircões de 19 afloramentos-chaves de diversas unidades estratigráficas, situadas na região oriental do Cráton São Francisco Meridional e nos orógenos Mineiro e Araçuaí. Visando estabelecer limites mais precisos do embasamento arqueano e a extensão real das sucessivas colagens proterozóicas, as amostras foram coletadas em diversos transectos E-W. Devido à evolução policíclica e/ou condições metamórficas de alto grau, a

(*) Os seguintes documentos citados no texto: Tabela 1 - localização geográfica das amostras; Tabelas 3 a 19 - resultados analíticos completos; descrição dos métodos e procedimentos analíticos podem ser acessados como anexos do artigo no no site www.sbgeo.org.br ou obtidos com o Autor Senior: 1 - CPRM/IG-UnB (Pesquisador Associado)/Pesquisador do CNPq. 2 - Research School of Earth Sciences - RSES, Australian National University - ANU, Canberra, Austrálial; 3 - CPMTC-IGC-UFMG/Pesquisador do CNPq, 4 - DEGEO/UFOT/Pesquisador do CNPq, 5 - IG-UnBIG/UnB/Pesquisador do CNPq, 6- CPRM.

Autor correspondente: luizcarlos@aneel.gov.br 
maioria das populações de zircão analisadas apresenta sistema isotópico U-Pb muito complexo e de interpretação não trivial. Os padrões morfológicos dos zircões sugerem combinações de herança isotópica, recristalização parcial e crescimento magmático e metamórfico de novos cristais e domínios de grãos. Por esse motivo, somente com detalhados estudos de catadoluminescência as idades dos zircões herdados, dos sobrecrescimentos magmáticos e dos grãos parcial ou totalmente recristalizados puderam ser diferenciadas. Isto tornou possível a segura distinção entre idades de cristalização magmática e de metamorfismo. Na borda sudeste do cráton, 5 amostras confirmaram idades arqueanas no intervalo ca. 3000-2700 Ma sendo que a maior parte delas também apresenta idades mal definidas de recristalização metamórfica entre ca. 2850$550 \mathrm{Ma}$. Gnaisses TTG expostos a leste e sul do Quadrilátero Ferrífero, anteriormente correlacionados ao embasamento arqueano, forneceram idades de cristalização magmática de $c a .2210$ a 2050 Ma e idades de recristalização metamórfica de ca. $2100 \mathrm{Ma}$ e $560 \mathrm{Ma}$. Estes gnaisses são, portanto, derivados de protólitos magmáticos do Cinturão Mineiro. A idade de $c a .1740 \mathrm{Ma}$ obtida em um granito alcalino da Suíte Borrachudos, intrusivo no embasamento arqueano da região a leste da Serra do Espinhaço Meridional, corrobora outras datações U-Pb do magmatismo anorogênico do rift Espinhaço. Exposições de embasamento situadas no núcleo do Orógeno Araçuaí, tais como o granulito charnockítico do Caparaó e um anfibolito do Complexo Pocrane, forneceram idades de cristalização magmática de ca. $2195 \mathrm{Ma}$ e de ca. $1500 \mathrm{Ma}$, respectivamente. Em ambos os casos, a idade do sobrecrescimento metamórfico em torno de $590 \mathrm{Ma}$ ficou bem estabelecida. O gnaisse granítico subalcalino da Suíte Salto da Divisa forneceu idade de cristalização magmática de ca. $870 \mathrm{Ma}$, similar às idades U-Pb do magmatismo relacionado à abertura do rift neoproterozóico na contraparte africana do Orógeno Araçuaí. Quatro granitóides gnaissificados do Orógeno Araçuaí (três deles antes corrrelacionados ao embasamento arqueano/ paleoproterozóico) forneceram idades entre ca. 560 e ca. $570 \mathrm{Ma}$, sendo contemporâneos ao magmatismo sincolisional $\left(\gamma_{2}\right)$ deste orógeno. Bordas de zircões do granitóide mais velho (Granito Nanuque) de ca. $570 \mathrm{Ma}$, apontam idades de alteração pós-magmática de ca. $500 \mathrm{Ma}$, similares a outras idades U-Pb obtidas em zircão, titanita e monazita, que são interpretadas como balizadoras do colapso do Orógeno Araçuaí.

Palavras-chaves: Análises U-Pb SHRIMP, orógenos Araçuaí e Mineiro, Cráton São Francisco

INTRODUÇÃo O Cráton São Francisco é uma unidade geotectônica neoproterozóica individualizada em decorrência da evolução dos orógenos brasilianos que o contornam. Os limites do Cráton são traçados com base nas variações da deformação das rochas supracrustais e envolvimento do embasamento cratônico pela Orogênese Brasiliana (e.g., Almeida 1977, Alkmim et al. 1993), como parcialmente ilustrado na figura 1. Entretanto, o embasamento do cráton, que resultou de colagens orogênicas anteriores à Orogênese Brasiliana, foi envolvido em intensidade variável nos orógenos brasilianos pericratônicos o que, aliado à natureza policíclica dos terrenos do embasamento dificulta sobremaneira a identificação da extensão dos segmentos arqueanos e paleoproterozóicos do substrato do cráton.

Os novos dados geocronológicos aqui apresentados e discutidos visam esclarecer problemas estratigráfico-tectônicos evidenciados durante a execução do Mapa Geológico, Tectônico e de Recursos Minerais do Brasil, Escala 1: 2.500.000-SIG (Bizzi et al. 2002) e do programa Carta Geológica do Brasil ao Milionésimo-SIG. Visando consolidar as cartas, foram executados transectos situados no domínio sudeste do cráton e no Orógeno Araçuaí, com amostragem para estudos isotópicos. A escassez de determinações geocronológicas por métodos precisos de alta resolução (U-Pb SHRIMP) constituiu, hoje, o maior fator restritivo à delimitação da extensão do embasamento cratônico, pois a natureza policíclica dos terrenos arqueanos e paleoproterozóicos da região restringe os resultados de métodos mais tradicionais (e.g. Rb-Sr, K-Ar, e mesmo U-Pb), os quais podem fornecer a idade apenas do último evento geológico ou uma intermediária entre eventos tectônicos superpostos $(e . g$., Carneiro 1992, Carneiro et al. 1998). Para melhor esclarecer as relações cronoestratigráficas entre distintas rochas de alto grau metamórfico (gnaisses bandados e granulitos) do embasamento cratônico e de rochas similares do Orógeno Araçuaí e caracteri- zar com mais precisão o Cinturão Mineiro, selecionou-se 19 amostras em função de sua representatividade cartográfica, com localização georreferen-ciada conforme a Tabela 1 (Anexo). A síntese dos resultados obtidos constam da Tabela 2 .

\section{EXTENSÃOORIENTALDOEMBASAMENTOARQUEANO DO CRÁTON SÃO FRANCISCO MERIDIONAL COM O} objetivo mencionado no item anterior, foram executados diversos perfis de direção geral E-W atravessando o domínio sudeste do Cráton São Francisco e dois orógenos superpostos, o Cinturão Mineiro do Paleoproterozóico e o Orógeno Araçuaí do Neoproterozóico.

A borda sudeste do Cráton São Francisco Meridional e terrenos adjacentes são constituídos por gnaisses bandados TTG (tonalito-trondhjemito-granodiorito) de fácies anfibolito, localmente na fácies granulito. Estas rochas constituem unidades tectono-magmáticas heterogêneas, policíclicas, cuja evolução se deve aos eventos tectonometamórficos de colagens orogênicas sobrepostas desde o Arqueano ao Neoproterozóico (Fig. 1). Os regimes tectônicos tangenciais do Neoproterozóico caracterizam-se por movimento de massa contra o Cráton São Franscisco. Os sistemas de cavalgamento implantaram-se, regionalmente, sob condições gerais de médio e alto strain e grau metamórfico, imprimindo às distintas unidades uma série de tectofácies similares, ou seja: ortognaisses com alternância de bandas metatonalíticas, trondhjemíticas e anfibolíticas (gnaisses bimodais), e venulações e bolsões de mobilizados graníticos. Em zonas de alto strain ocorrem tectonitos LS com avançada transposição e paralelização das estruturas anteriores. Apesar do resultado final da transposição tectônica ter gerado gnaisses "homogêneos" e, aparentemente, monocíclicos, sua evolução prévia é melhor determinada por meio do método SHRIMP. 
Tabela 2 - Sintese dos resultados obtidos

\begin{tabular}{|c|c|c|c|c|c|c|}
\hline A mostra & Localidade & $\begin{array}{l}\text { Classificação } \\
\text { petrográfica }\end{array}$ & $\begin{array}{c}\text { Designação } \\
\text { litoestratigráfica }\end{array}$ & $\begin{array}{c}\text { Idade } \\
\text { aproximada } \\
\text { previamente } \\
\text { admitida }\end{array}$ & $\begin{array}{c}\text { Idade de } \\
\text { Cristalização } \\
\text { SHRIM P (Ma) }\end{array}$ & $\begin{array}{c}\text { Idade } \\
\text { metamórfica } \\
\text { SHR IM P } \\
(\text { M a })\end{array}$ \\
\hline \multicolumn{7}{|c|}{ Limite sudeste do embasamento arqueano retrabalhado do Cráton São Francisco } \\
\hline LC 18 & $\begin{array}{c}\text { Pedreira de Lima } \\
\text { Duarte }\end{array}$ & $\begin{array}{l}\text { BT guaisse } \\
\text { lonalítico }\end{array}$ & $\begin{array}{c}\text { Ortognaisse Lima } \\
\text { Duarte } \\
\end{array}$ & arque:sina & $2777+22$ & $1137 \pm 280 \mathrm{ii}$ \\
\hline LC 17 & Pedreira de fuiz de Fora & $\begin{array}{c}\text { OPx-BT } \\
\text { glanulito } \\
\text { cnderbítico } \\
\end{array}$ & $\begin{array}{c}\text { Complexo de Juiz de } \\
\text { Fora }\end{array}$ & $2150 \mathrm{M} a$ & $2985 \pm 17$ & $\begin{array}{l}\text { MI } 2856 \pm 44 \\
808 \pm 360 \mathrm{ii}\end{array}$ \\
\hline LC 12 & Pedreira de Barbacenat & $\begin{array}{l}\text { BT gnaisse } \\
\text { conalítico }\end{array}$ & Complexo Mantiqueira & arquean il & n.d. & $2068 \pm 19$ \\
\hline LC45 & Norle de Coluna & $\begin{array}{c}\text { B T gnaissc } \\
\text { tondhjemito }\end{array}$ & Complexo Guanhães & arqueana & $2867 \pm 10$ & \\
\hline LC $43 \mathrm{~A}$ & $\begin{array}{c}\text { Pedreira de São João } \\
\text { Evangelista }\end{array}$ & $\begin{array}{l}\text { B T Ionalito } \\
\text { gnaisse }\end{array}$ & Complexo Guanhacs & arclucana & $2711 \pm 11$ & $\begin{array}{c}527 \pm 45 \mathrm{ii} \\
519 \pm 5(1 \sigma)\end{array}$ \\
\hline LC 44 & $\begin{array}{c}\text { Pedreira de São Pedro } \\
\text { do Suaguí }\end{array}$ & Lettcogranito & Complexo Guanhates & $2530 \mathrm{Ma}$ & $2710 \pm 6$ & $497 \pm 68 \mathrm{ii}$ \\
\hline LC 30 & Pedreira de Ponte Nova & $\begin{array}{l}\text { HB-BTgnaisse } \\
\text { tonalítico }\end{array}$ & Complexo Piedade & arqueana & 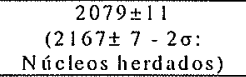 & \\
\hline LC 21 & $\begin{array}{c}\text { Proximidades de } \\
\text { Piedade }\end{array}$ & $\begin{array}{l}\text { Biotita gnaisse } \\
\text { tonalítico }\end{array}$ & Complexo Piedade & arqueana & $\begin{array}{c}2102 \pm 8 \\
(2186 \pm 13-2 \sigma: \\
\text { Nícleos herdados) }\end{array}$ & \\
\hline LC I3A & Pedreira de Rio Pomba & $\begin{array}{l}\mathrm{HB}-\mathrm{BT} \text { gnaisse } \\
\text { tonalítico }\end{array}$ & Complexo Piedade & arqucana & $\begin{array}{c}2169 \pm 44 \\
(2208 \pm 46-1 \sigma: \\
\text { Núcleo herdado })\end{array}$ & $\begin{array}{c}M_{1} 2028 \pm 66 \\
M=540 \pm 11 \\
(1 \sigma)\end{array}$ \\
\hline LC 16 & $\begin{array}{c}\text { Pedreira de Ewbank da } \\
\text { Câmala }\end{array}$ & $\begin{array}{c}C P x-H B-B T \\
\text { gianse tonalítico }\end{array}$ & Complexo Piedade & arqueana & $\begin{array}{c}2058 \pm 7 \\
(2100 \pm 6-10: \\
\text { Núcleo herdado) }\end{array}$ & $443 \pm 240 \mathrm{ii}$ \\
\hline LC 26 & Estradia de São Tiago & $\begin{array}{c}\text { HB Grianodiorito } \\
\text { foliado }\end{array}$ & $\begin{array}{c}\text { Granodiorito foliado } \\
\text { São Tiago } \\
\text { (Batólito Ritápolis) }\end{array}$ & arqueana & $2050 \pm 12$ & $\begin{array}{c}565 \pm 23(1 \sigma) \\
233+160 \mathrm{ii}\end{array}$ \\
\hline \multicolumn{7}{|c|}{ Magmatismo intraplaca intrusivo nos gnaisses arqueanos do Complexo Guanhães: Suíte Borrachudos } \\
\hline LC 40 & & $\begin{array}{l}\text { HB-B T granito } \\
\text { gnáissico }\end{array}$ & $\begin{array}{l}\text { Granito Porto A qucena } \\
\text { (Sufte Borrachudos) }\end{array}$ & $1760 \mathrm{M} \mathrm{a}$ & $1740 \pm 8$ & \\
\hline \multicolumn{7}{|c|}{ Inliers do embasamento retrabalhado do Orógeno Araçuấ } \\
\hline LC 32 & Allo Caparaó & $\begin{array}{c}\text { OPX-BT } \\
\text { granulito } \\
\text { charnockítico } \\
\end{array}$ & Complexo Caparaó & $2150 / 585 \mathrm{Ma}$ & $2195 \pm 15$ & $587 \pm 9$ \\
\hline VP05 & Bananal & Anfibolito & Complexo Pocrine & arqucana & $1506 \pm 14$ & $602 \pm 14$ \\
\hline \multicolumn{7}{|c|}{ Magmatismo pré-orogênico da abertura do rifte Araçuaí setentrional $B A$} \\
\hline $\mathrm{JM} \mathrm{O7B}$ & Salto da Divisa & $\begin{array}{c}\text { Granilo guáissico } \\
\text { subalcalino }\end{array}$ & Granto Salto da Divisa & $\begin{array}{c}\text { arqueanal } \\
\text { palcoprolero-zóical }\end{array}$ & $875 \pm 9$ & \\
\hline \multicolumn{7}{|c|}{ Magmatismo sincolisional na borda ocidental e setentrional do Orógeno Araçuaí } \\
\hline LC 31 & $\begin{array}{l}\text { Pedreira de } \\
\text { Manhuacu }\end{array}$ & GD charnockito & Charnockito Minhuaçu & $2150 \mathrm{M} \mathrm{a}$ & $584 \pm 5$ & \\
\hline LC 38 & $\begin{array}{c}\text { Acesso de Goverinador } \\
\text { Valadares }\end{array}$ & $\begin{array}{l}\text { BT ginaisse } \\
\text { tonalítico }\end{array}$ & $\begin{array}{c}\text { Ortognaisse } \\
\text { Governidor Valadares I }\end{array}$ & arqueana & $565 \pm 31$ & \\
\hline LC 39 & $\begin{array}{c}\text { Acesso de Governador } \\
\text { Validares }\end{array}$ & $\begin{array}{l}\text { BT granodiorito } \\
\text { gnáissico }\end{array}$ & $\begin{array}{c}\text { Granodiorito Guíissico } \\
\text { Governador Valadares } \\
\text { lI }\end{array}$ & arqueana & $561 \pm 7$ & \\
\hline LC 48 & $\mathrm{~N}$ :nuque & $\begin{array}{l}\text { BT Granito } \\
\text { porfinitico } \\
\text { foliado }\end{array}$ & Granito Nanuque & $750 \mathrm{Ma}$ & $573 \pm 5$ & $\begin{array}{c}508 \pm 8(10) \\
\text { (Perda pós- } \\
\text { magmálica de Pb) } \\
\end{array}$ \\
\hline
\end{tabular}

Ortognaisse tonalítico de Lima Duarte (Amostra LC 18)

O local de amostragem (Fig. 1) situa-se no setor setentrional da Faixa Ribeira, segmento meridional do Orógeno Araçuaí. um ortognaisse TTG bandado, bimodal, com bandamento magmático e migmatítico proeminente, transposto e com mesodobras irregulares. Ao microscópio se classifica como biotita ortognaisse tonalítico da fácies anfibolito, com textura totalmente recuperada granoblástica poligonal fina (blastomilonítica), microbandado, foliado e com microvenulações de granito potásico.

Foram datados 13 spots em 13 cristais e os resultados analíticos constam da Tabela 3 e do diagrama concórdia da figura $2 a$. Sete spots pertencentes à mesma população magmática (MSWD $=0,97$ ) se alinham segundo uma discórdia com intercepto superior de $2777 \pm 22 \mathrm{Ma}$, interpretado como a idade de cristalização magmática. A mesma discórdia tem intercepto inferior impreciso que sugere distúrbio isotópico associado a evento metamórfico Proterozóico. O distúrbio é confirmado pela presença de finos sobrecrescimentos metamórficos externos de alta luminescência em catodoluminescência (CL) não datados devido às dimensões reduzidas. A amostra também contem uma população expressiva de núcleos herdados, o mais antigo com idade aparente de $3162 \pm 5 \mathrm{Ma}(1 \sigma)$.

A idade magmática de ca. 2777 Ma, com herança em ca. 3162 Ma é conhecida em outros gnaisses TTG do interior do Cráton São Francisco. Assim, os gnaisses de Lima Duarte poderiam representar fragmento do embasamento arqueano do cráton, preservado como substrato da Faixa Ribeira (Fig. 1). Por outro lado, sua localização relativamente distante do limite oriental do cráton, do qual está separado por por terrenos paleoproterozóicos, sugere que esses gnaisses podem ser parte de um segmento alóctone, amalgamado à borda cratônica durante a colagem paleoproterozóica ou neoproterozóica.

Granulito enderbítico de Juiz de Fora (Amostra LC 17) O local de amostragem também se situa no setor setentrional 


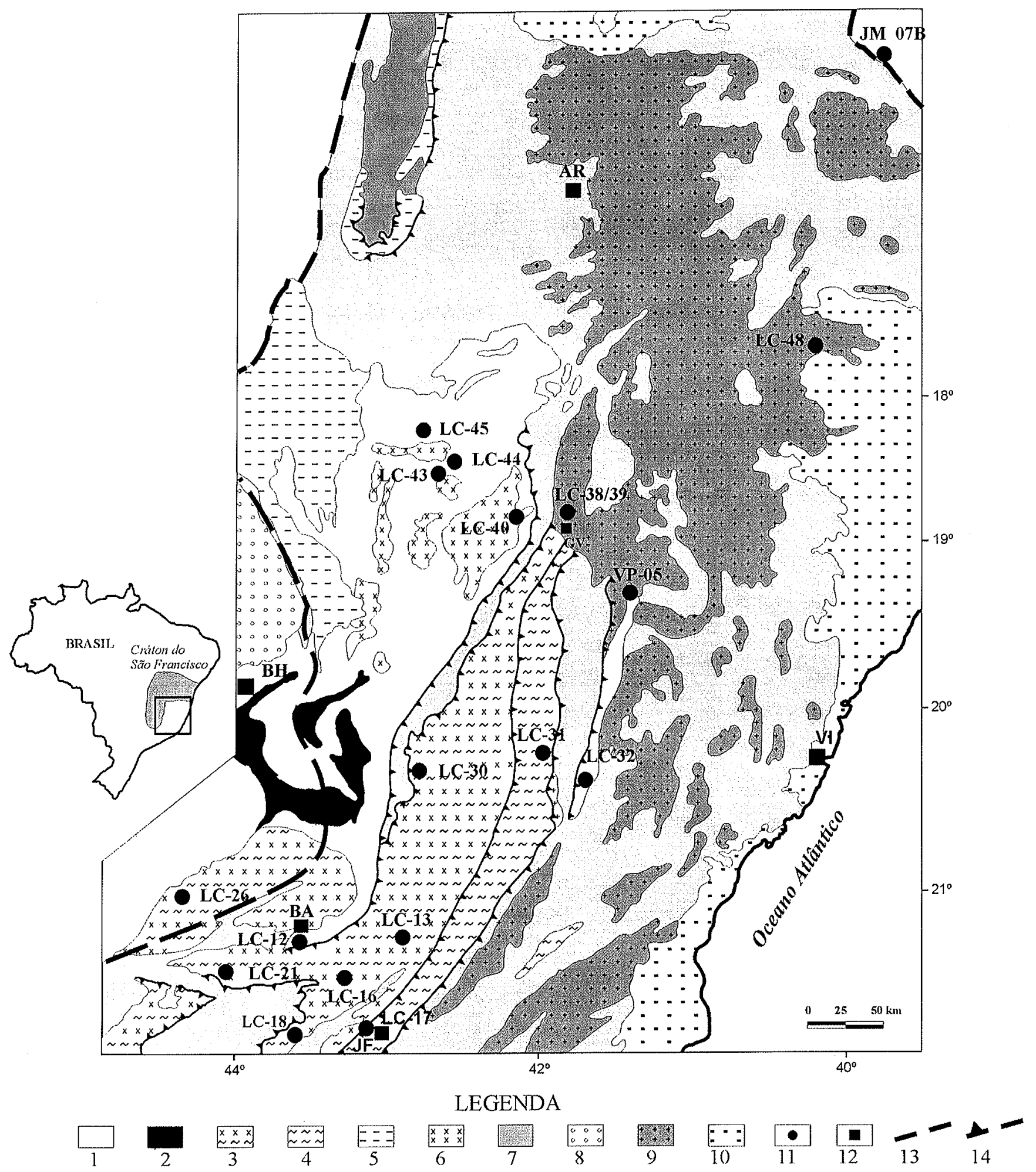

1. Terrenos granito-greenstone arqueanos; 2. Supergrupo Minas; 3. Complexo Piedade; 4.Complexo Juiz de Fora;

5. Supergrupo Espinhaço; 6. Suite Borrachudos; 7. Unidades supracrustais do Ciclo Brasiliano; 8. Grupo Bambuí;

9. Granitóides da Orogênese Brasiliana; 10.Coberturas fanerozóicas; 11. Amostra; 12. Cidade; 13. Limite do Cráton São Francisco; 14. Falhade empurrão. BA. Barbacena; AL. Almenara; VI. Vitória; BH. Belo Horizonte; JF. Juiz de Fora; GV. Governador Valadares; AR. Araçuaí.

Figura 1 - Compartimentação tectônica e limites do Cráton São Francisco e orógenos marginais em Minas Gerais e Espírito Santo (modificado de Pedrosa-Soares et al., 2001 e Silva et al. 2002a), com a localização das amostras. 

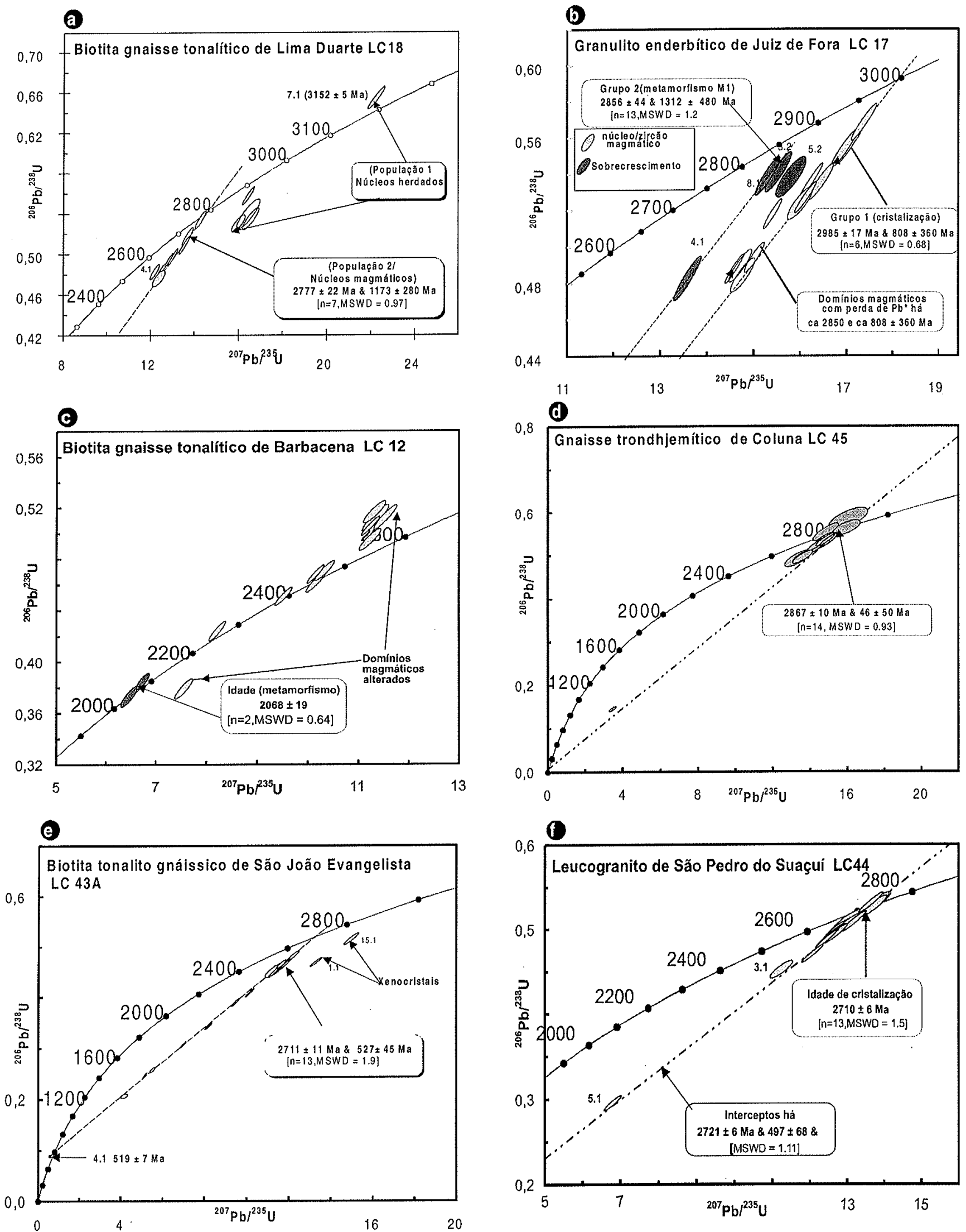

Figura 2 - Diagramas concórdia das amostras: a) LC 18; b) LC 17; c) LC 12 ; d)LC 45 ; e) LC 43A;f) LC 44 
da Faixa Ribeira (Fig. 1).

A amostra provem de uma pedreira da cidade homônima, no domínio do Complexo Juiz de Fora de idade paleoproterozóica (Fig. 1). É um ortognaisse enderbítico cinza-esverdeado, bandado, bimodal, parcialmente migmatizado, com forte microbandamento. Ao microscópio, se classifica como biotita-ortopiroxênio ortognaisse enderbítico (granulito), com textura recuperada granoblástica poligonal fina (blastomilonítica) a porfiroclástica, com foliação microdobrada, dada por minerais máficos.

Foram datados 16 spots em 13 cristais de zircão e os resultados constam da Tabela 4 e do diagrama da figura $2 b$. Seis spots pertencentes à mesma população de núcleos magmáticos $(\mathrm{MSWD}=0.61)$ alinham-se segundo uma discórdia com intercepto superior de $2985 \pm 17 \mathrm{Ma}$, interpretado como a idade de cristalização magmática. A discórdia mostra um intercepto inferior impreciso de $808 \pm 360 \mathrm{Ma}$, sugestivo de distúrbio isotópico no Proterozóico.

Os spots datados nas bordas dos cristais apresentam fino sobrecrescimento, com alta luminescência em CL (baixo U), de origem metamórfica. Três spots pertencentes à mesma população $(M S W D=1,2)$ alinham-se segundo uma discórdia com intercepto superior de $2856 \pm 44 \mathrm{Ma}$, interpretado como a idade do metamorfismo de fácies granulito $M_{1}$. A discórdia tem intercepto inferior impreciso de $1312 \pm 480$ Ma.

A cartografia do Complexo Juiz de Fora engloba amplos segmentos de ortognaisses enderbíticos do embasamento das faixas Araçuaí e Ribeira, com idades U-Pb convencionais de cristalização magmática em ca. $2150 \mathrm{Ma}$ e de metamorfismo em $590 \mathrm{Ma}$ (SöIner et al. 1991). Os resultados obtidos de ca. 3000 Ma para a cristalização e de ca. $2850 \mathrm{Ma}$ do metamorfismo de alto grau, são distintos das idades previamente publicadas. A rigor, na cidade de Juiz de Fora afloram distintos conjuntos de rochas (Duarte 1998), pertencentes ao Complexo Juiz de Fora e a outras unidades. Assim, a presença de granulitos arqueanos nesta área é interpretada de forma semelhante aos gnaisses de Lima Duarte, como possíveis domínios alóctones.

Ortognaisse tonalítico de Barbacena (Amostra LC 12) O afloramento também se localiza no setor setentrional da Faixa Ribeira (Fig. 1). É um ortognaisse TTG bandado, bimodal, com bandamento composicional e migmatítico transposto, com mesodobras irregulares e metamorfisado em fácies anfibolito. Ao microscópio se classifica como biotita ortognaisse tonalítico com textura recuperada granoblástica poligonal fina (blastomilonito), com raros porfiroclastos de plagioclásio magmático. A foliação é dada por biotita.

Nesta amostra datou-se 15 spots em 14 cristais, cujos resultados analíticos constam da Tabela 5 e do diagrama da Figura 2c. Devido a problemas analíticos, os resultados devem ser interpretados com cautela. $\mathrm{O}$ agrupamento principal, obtido em uma população homogênea de núcleos magmáticos forneceu idade aparente de ca. $2500 \mathrm{Ma}$ com acentuada discordância reversa, não permitindo a determinação de idade de cristalização confiável. Além disso, esse resultado deve ser melhor avaliado, pois todas as unidades de gnaisses da porção meridional do cráton têm fornecido idades iguais ou superiores a $2780 \mathrm{Ma}$ (Machado \& Carneiro 1992, Teixeira et al. 1998, Noce et al. 1998). Por isso, re- quer-se datações adicionais para verificar a consistência da idade obtida neste trabalho.

Dois spots situados em bordas luminescentes de baixo U (metamórficas) forneceram idade de $2068 \pm 19 \mathrm{Ma}$, interpretada como a de metamorfismo na fácies anfibolito. Essa idade é compatível com a da orogênese paleoproterozóica registrada no Cinturão Mineiro, cujo evento colisional data de $c a 2080 \mathrm{Ma}$ (ver adiante).

Ortognaisse tonalítico de Coluna (Complexo Guanhães) (Amostra LC 45) A amostra foi coletada em corte de rodovia ao norte da cidade homônima, em afloramento do embasamento da Faixa Araçuaí (Fig. 1). Trata-se de ortognaisse TTG bandado, bimodal, com forte bandamento (cm) magmático e migmatítico transposto e com mesodobras irregulares. Ao microscópio se classifica como biotita leucoortognaisse trondhjemítico, intercalado com microbandas tonalíticas, com textura recuperada granoblástica poligonal grossa, fortemente foliado, de fácies anfibolito.

Foram datados 14 spots em 10 cristais, cujos dados analíticos constam da Tabela 6 e os resultados da Figura 2 d. Os dados dos 14 spots pertencentes à mesma população de núcleos magmáticos (MSWD =0,93) aglomeram-se em torno de $2867 \pm 10 \mathrm{Ma}$, interpretada como a de cristalização do magma tonalítico. A população mostra um intercepto inferior impreciso de $46 \pm 50 \mathrm{Ma}$ sugestivo de perda de $\mathrm{Pb}$ em tempo recente.

Ortognaisse tonalítico de São João Evangelista (Complexo Guanhães) (Amostra LC 43A) A amostra coletada em pedreira nas proximidades da cidade homônima, também em afloramento do embasamento da Faixa Araçuaí (Fig. 1). É um ortognaisse TTG de granulação grossa, bandado, bimodal, com acamamento $(\mathrm{cm})$ magmático e migmatítico transposto, com mesodobras irregulares. Ao microscópio se classifica como biotita leuco-ortognaisse trondhjemítico, de textura recuperada granoblástica-poligonal grossa, foliado e da fácies anfibolito. Petrograficamente é bastante similar à amostra anterior, porém sem intercalações de microbandas trondhjemíticas.

Os dados analíticos de 16 spots em 16 cristais constam da Tabela 7 e do diagrama da figura $2 \mathrm{e}$. Treze spots pertencentes à mesma população de núcleos magmáticos (MSWD = 1,9) formam um aglomerado discordante que se alinha segundo uma discórdia, com intercepto superior em $2711 \pm 11$ $\mathrm{Ma}$, interpretado como a idade de cristalização magmática. A discórdia tem intercepto inferior impreciso em $527 \pm 45$ $\mathrm{Ma}$, sugestivo de distúrbio isotópico relacionado ao brasiliano. Um spot situado em sobrecrescimento, de baixo $\mathrm{Th}$ (metamórfico) forneceu idade ${ }^{206} \mathrm{~Pb} /{ }^{238} \mathrm{U}$ aparente de 519 \pm 7 (1s), interpretada como a idade aproximada de metamorfismo na fácies anfibolito ocorrido na fase tardia da Orogênese Brasiliana. Considerando as idades U-Pb similares, obtidas em zircão e titanita do Complexo Guanhães (Machado et al. 1989, Fernandes 2001) e a idade (520-500 Ma) da granitogênese pós-colisional da Faixa Araçuaí, esta perturbarção tardia pode ter resultado do colapso extensional do orógeno brasiliano.

Leucogranito de São Pedro do Suaçuí (Complexo Guanhães) (Amostra LC 44) A amostra foi coletada em 
pedreira nas proximidades da cidade homônima, em afloramento do embasamento da Faixa Araçuaí (Fig. 1). Trata-se de leucogranito sem foliação tectônica, intrusivo em ortognaisses. Ao microscópio, é um (muscovita)-biotita leucogranito, de com textura hipidiomórfico-granular grossa.

Os dados analíticos de 15 spots em 14 cristais constam da Tabela 8 e do diagrama da figura $2 \mathrm{f}$. Treze spots da mesma população de núcleos magmáticos $(\mathrm{MSWD}=1,5)$ formam um aglomerado com média das razões ${ }^{207} \mathrm{~Pb} /{ }^{206} \mathrm{~Pb}$ de $2710 \pm 6$ $\mathrm{Ma}$, interpretada como a idade de cristalização magmática. A mesma população forma um agregado discordante com interceptos de $2721 \pm 6 \mathrm{Ma}$ e $497 \pm 68 \mathrm{Ma}$. O intercepto inferior sugere distúrbio do sistema isotópico durante fase tardia, provavelmente relacionada ao colapso extensional da Orogênese Brasiliana.

A datação de duas amostras dos gnaisses bandados de maior expressão cartográfica no Complexo Guanhães (Pedrosa-Soares et al. 1994) confïmou sua idade arqueana. A sua caracterização como "paragnaisses do Grupo Guanhães" (Grossi-Sad et al. 1990) necessita de revisão, pois estas rochas representam tectofácies (tectonitos LS) de ortognaisses bandados TTG. É importante ressaltar que as idades em torno de 2860 e $2710 \mathrm{Ma}$ obtidas em gnaisses e granitóide do Complexo Guanhães, correspondem a eventos tectono-magmáticos bem estabelecidos no embasamento arqueano, domínio cratônico, do Quadrilátero Ferrífero (Machado et al. 1992, Machado \& Carneiro 1992, Noce et al. 1998). Consequientemente, os dados aqui obtidos sugerem que o Complexo Guanhães pode corresponder a uma extensão deste substrato no domínio da Faixa Araçuaí, e não um terreno alóctone, como discutido na literatura.

\section{PLUTONISMO OROGÊNICO PALEOPROTEROZÓICO}

Parte do embasamento das faixas Araçuaí e Ribeira foi denominado de Complexo Mantiqueira, de idade controversa, Arqueano e/ou Paleoproterozóico (e.g., Figueiredo \& Teixeira 1996). Estes autores interpretam o Complexo Mantiqueira como registro de um arco magmático maduro, desenvolvido em margem continental ativa, com retrabalhamento de crosta arqueana e rejuvenescimento no intervalo $550-500 \mathrm{Ma}$.

Foram datados 4 amostras de ortognaisses desta unidade, a qual constitui extensa faixa de ortognaisses TTG empurrados sobre a margem cratônica e remanescentes das supracrustais do Orógeno Araçuaí (Grupo Dom Silvério)(Fig. 1). São ortognaisses extensivamente recristalizados na fácies anfibolito. Em zonas de baixo strain contém proeminente bandamento composicional e/ou metamórfico, dado pela alternância de bandas tonalíticas, trondhjemíticas e anfibolíticas (gnaisses bimodais), com venulações e bolsões de mobilizados graníticos. Em zonas de alto strain, são tectonitos LS e incluem ultramilonitos e filonitos (amostras LC 13A, LC16, LC 21). Embora nessas amostras a forte deformação tenha transposto e paralelizado estruturas anteriores, a presença de schlieren concordantes de biotita sugere fusão parcial pré- e/ou sintectônica. Essas feições seriam responsáveis pela obliteração das bandas migmatíticas originais, dando origem a uma tectofácies gnáissica aparentemente homogênea, peculiaridade com importantes consequiências para a interpretação dos resultados isotópicos.

Uma quinta amostra (LC 26), de granodiorito foliado não pertencente à unidade de gnaisses bandados, mas situada no inte- rior do cráton e adjacente ao Batólito Ritápolis (Fig. 1) de idade paleoproterozóica, foi também datada para comparação.

\section{Ortognaisse tonalítico de Ponte Nova/Complexo Piedade} (Amostra LC 30) A amostra foi coletada no embasamento da Faixa Araçuaí a sudeste do Grupo Dom Silvério (Fig. 1). É um gnaisse tonalítico fino, com intercalações tectônicas concordantes de largura métrica a decamétrica, de rochas supracrustais anfibolíticas e calcissilicáticas. Ao microscópio é um hornblenda-biotita ortognaisse tonalítico, da fácies anfibolito, com textura recuperada granoblástica alongada fina e forte foliação dada pelos minerais máficos. Raros porfiroclastos magmáticos de hornblenda e plagioclásio estão preservados.

Os dados analíticos de 16 spots em 14 cristais constam da Tabela 9 e do diagrama da figura $3 \mathrm{a}$. Cinco spots pertencentes à mesma população de núcleos herdados forneceram idade ${ }^{207} \mathrm{~Pb} /{ }^{206} \mathrm{~Pb}$ aparente de $2167 \pm 7 \mathrm{Ma}$. Sete spots, situados em sobrecrescimentos magmáticos internos, forneceram idade ${ }^{207} \mathrm{~Pb} /{ }^{206} \mathrm{~Pb}$ aparente de $2079 \pm 11 \mathrm{Ma}$, interpretado como a idade de cristalização magmática. Três spots situados em domínios alterados de uma mesma população $(\mathrm{MSWD}=1,08)$ forneceram idade aparente de $2044 \pm 8 \mathrm{Ma}$, interpretada como resultante de distúrbio isotópico após a cristalização magmática. Os cristais apresentam fino sobrecrescimento externo metamórfico fortemente luminescente em CL, possivelmente resultante do evento neoproterozóico.

\section{Ortognaisse tonalítico de Piedade do Rio Grande/Comple-} xo Piedade (Amostra LC 21) $A$ amostra provem de afloramento da Faixa Ribeira situado em corte de rodovia próxima à cidade homônima. É um gnaisse ultramilonítico finamente bandado, e lenticularizado (LS tectonito). Ao microscópio é um biotita gnaisse ultramilonítico de composição tonalítica, da fácies anfibolito, com textura recuperada granoblástica alongada e foliação dada pela orientação de mica. A rocha possui raros remanescentes de porfiroclastos lenticularizados de plagioclásio.

Os resultados analíticos de 16 spots em 14 cristais constam da Tabela 10 e dos diagramas das figuras $3 \mathrm{~b}$ e $3 \mathrm{c}$. Seis spots pertencentes à mesma população de núcleos herdados $(M S W D=0,60)$ forneceram idade ${ }^{207} \mathrm{~Pb} /{ }^{206} \mathrm{~Pb}$ aparente de $2186 \pm 13 \mathrm{Ma}$. Cinco spots obtidos em uma mesma popula. ção (MSWD $=1,8$ ) de domínios magmáticos internos forneceram idade aparente de $2102 \pm 8 \mathrm{Ma}$, interpretado como a de cristalização magmática. Os cristais também apresentam fino obrecrescimento externo metamórfico.

Ortognaisse tonalítico de Rio Pomba/Complexo Piedade (Amostra LC 13A) O afloramento se localiza na Faixa Ribeira, em pedreira próxima a Rio Pomba (Fig. 1). É um ortognaisse ultramilonítico finamente bandado e lenticularizado (LS tectonito). Ao microscópio é um hornblenda-biotita gnaisse da fácies anfibolito, com textura recuperada granoblástica alongada e forte orientação de minerais máficos.

Os resultados analíticos de 17 spots em 11 cristais constam da Tabela 11 e do diagrama da figura $3 \mathrm{~d}$. O principal grupo foi datado em núcleos magmáticos que apresentam forte dispersão ao longo da Concórdia (MSWD $=11,6$ ), o que dificulta a obtenção de uma idade confiável. Oito spots 
Reavaliação da evolução geológica em terrenos pré-cambrianos brasileiros com base em novos dados U-Pb SHRIMP, Parte II...

\section{a}

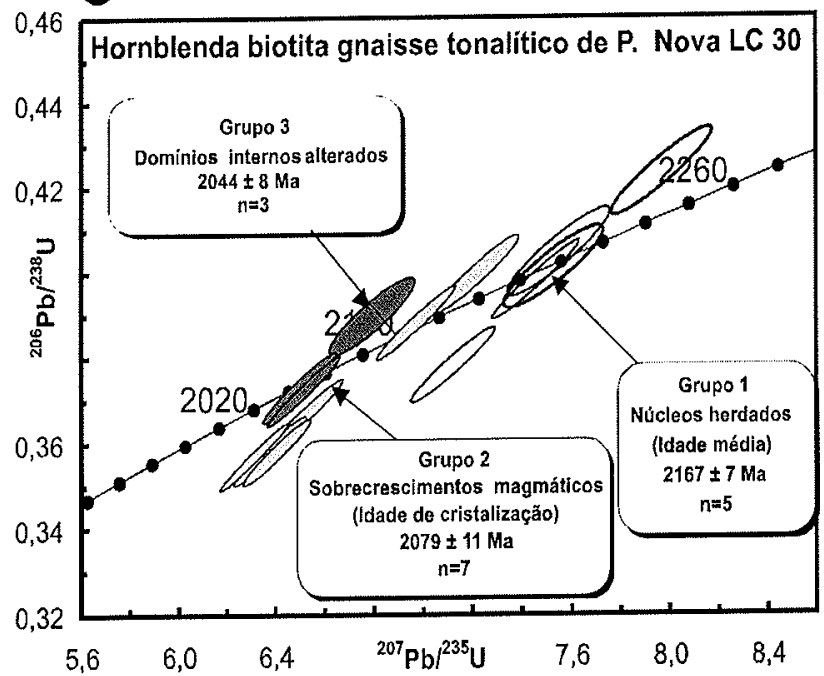

C

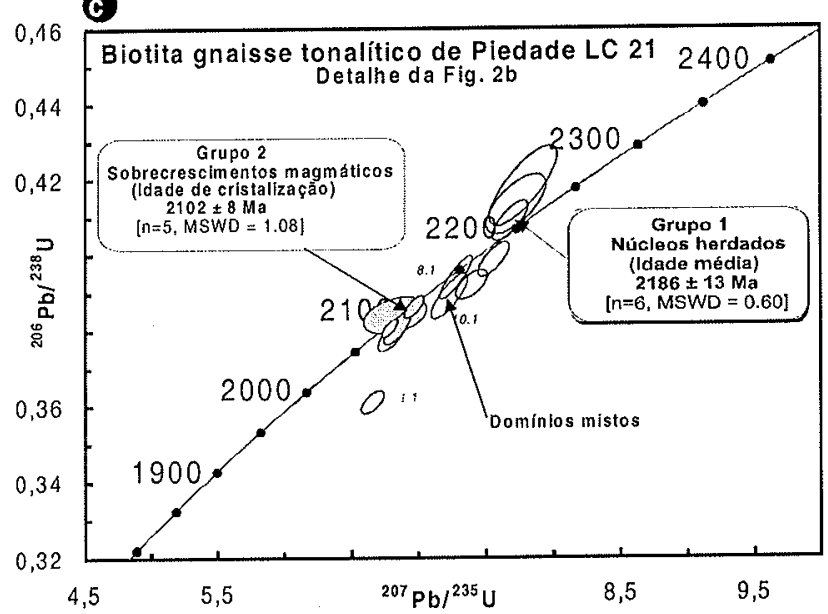

e

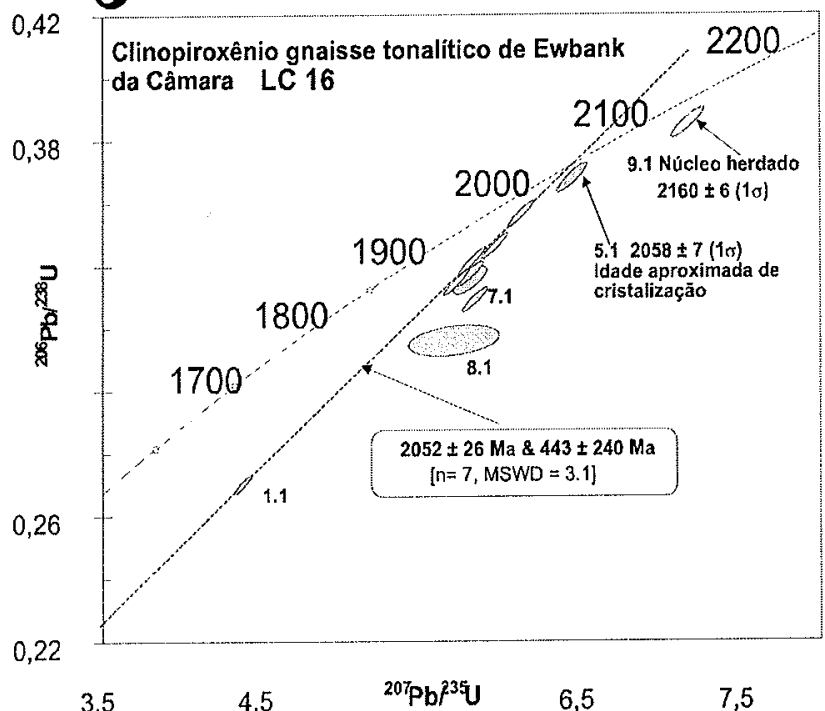

(b

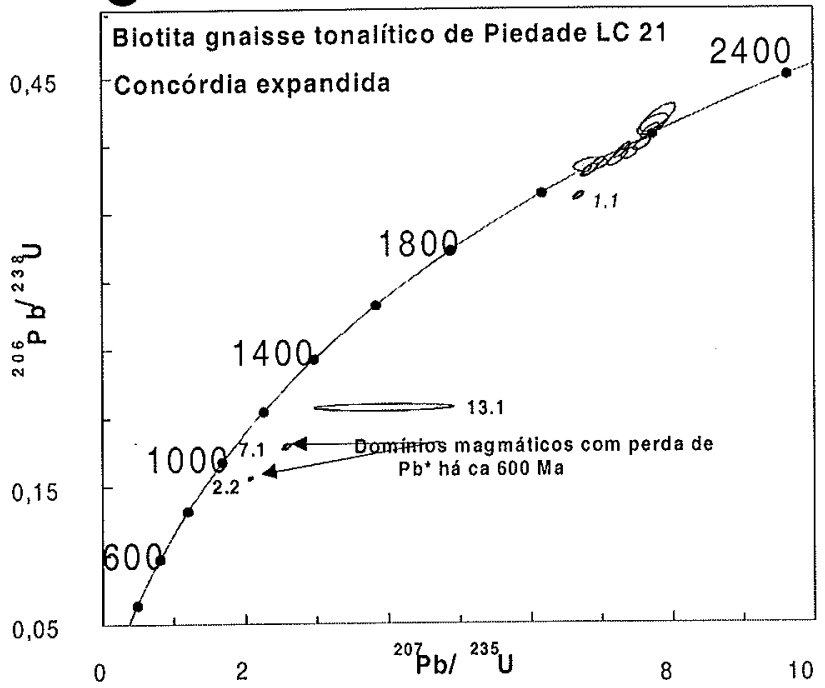

a
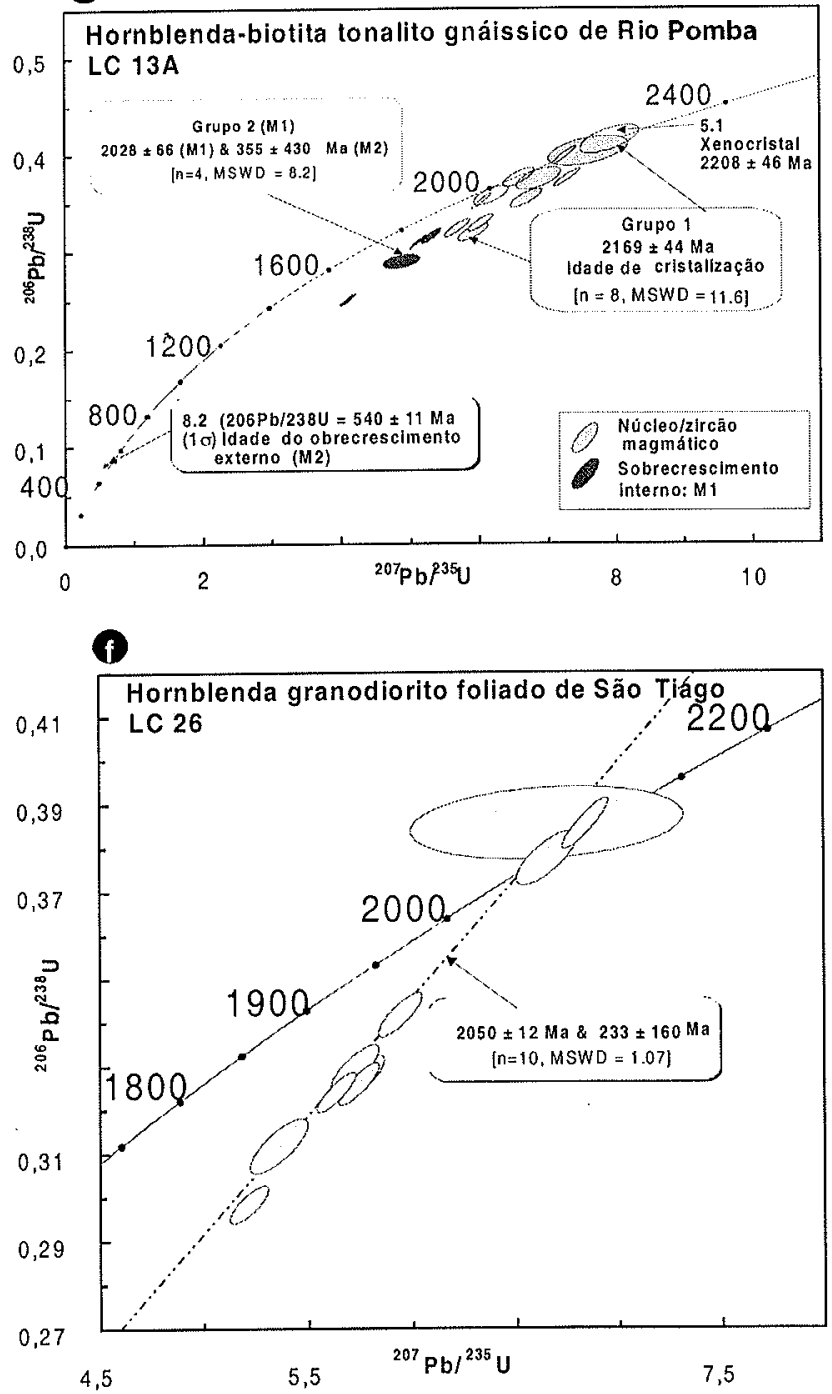

Figura 3 - Diagramas concórdia das amostras: a) LC 30; b) LC 21 (concordia expandida); c) LC 21 (detalhe da Fig . 2a); d) $L C 13 A$; e) LC 16; f) LC 26; f) LC 40. 
situados nesses núcleos forneceram uma idade imprecisa de $2169 \pm 44$ Ma que, apesar do elevado erro analítico, pode ser considerada como a melhor aproximação para a idade de cristalização magmática. O spot 5.1 , com idade aparente de 2208 $\pm 46 \mathrm{Ma}$, foi descartado devido à morfologia distinta dos demais cristais, e interpretado como xenocristal. Quatro análises concordantes foram obtidas em sobrecrescimentos internos caracteristicamente metamórficos, mas com altos teores de $\mathrm{U}$ e $\mathrm{Pb}$. Apesar da considerável dispersão dos dados dessa população (MSDW $=8,2$ ), ela caracteriza um trend com intercepto superior impreciso de $2028 \pm 66 \mathrm{Ma}$, interpretado como a idade de um primeiro evento metamórfico $\left(\mathrm{M}_{1}\right)$ que afetou o gnaisse. O spot 8.2 , obtido em um sobre-crescimento metamórfico externo, caracterizado por alta luminescência em $\mathrm{CL}$ (baixo $\mathrm{U}$ ), forneceu a idade ${ }^{206} \mathrm{~Pb} /{ }^{238} \mathrm{U}$ de $540 \pm 11 \mathrm{Ma}(1 \sigma)$, a melhor aproximação da idade do segundo evento metamórfico $\left(\mathrm{M}_{2}\right)$ do gnaisse.

Ortognaisse tonalítico de Ewbank da Câmara/Complexo Piedade (Amostra LC 16) O afloramento localiza-se no domínio da Faixa Ribeira, em pedreira próxima à cidade homônima (Fig. 1). É um gnaisse ultramilonítico, finamente bandado e lenticularizado (LS tectonito). Ao microscópio, é um clinopiroxênio-hornblenda-biotita gnaisse tonalítico, da transição entre as fácies anfibolito e granulito, com textura recuperada granoblástico alongada grossa e forte foliação microdobrada, dada por minerais máficos. A rocha contem raros porfiroclastos lenticularizados de plagioclásio.

Os resultados analíticos de 11 spots em 9 cristais constam da Tabela 12 e do diagrama da figura $3 \mathrm{e}$. Sete spots pertencentes à mesma população de núcleos magmáticos, apesar da relativa dispersão (MSWD $=3,1$ ), formam um aglomerado discordante alinhado em uma discórdia com intercepto superior de $2052 \pm 26$ $\mathrm{Ma}$, interpretada como a idade de cristalização magmática. $\mathrm{O}$ Spot 5.1, datado em um núcleo magmático, gerou idade ${ }^{207} \mathrm{~Pb} /$ ${ }^{206} \mathrm{~Pb}$ aparente de $2058 \pm 7 \mathrm{Ma}(1 \sigma)$ que, pela boa concordância, pode ser interpretada como a melhor estimativa da idade de cristalização do magma precursor. O spot 9.1 , situado em um núcleo herdado, apresenta idade de cristalização de $2160 \pm 6$ $(1 \sigma)$.

Os núcleos herdados dos cristais das amostras LC 30 e LC 21 forneceram idades situados no mesmo intervalo (2180$2160 \mathrm{Ma})$. Apesar das incertezas quanto à natureza da(s) fontes pela grande reprodutibilidade regional, esses dados podem ser interpretados como a idade aproximada da crosta continental assimilada pelo magma tonalítico precursor dos gnaisses. Como a amostra LC-31 possui idade de cristalização no mesmo intervalo (2169 Ma), pode-se supor que esses gnaisses pertençam a uma unidade heterogênea (arco magmático) que inclui fases pré-colisionais acrescidas há ca. $2160 \mathrm{Ma}$, rapidamente recicladas pelo magmatismo sincolisional, ocorrido no intervalo 2100-2050 Ma (Tab. 2).

\section{Granodiorito gnáissico de São Tiago (Amostra LC 26)}

afloramento situa-se na extremidade sudeste do Cráton São Francisco meridional, nas proximidades da cidade homônima, adjacente e se associa ao batólito paleproterozóico Ritápolis (Fig. 1). É um granodiorito foliado, intrusivo nos ortognaisses do embasamento arqueano do cráton dos quais exibe diversos xenólitos, apesar de ter sido cartografado como pertencente ao embasamento arqueano (Tabela 2). Ao microscópio, é um hornblenda granodiorito gnaisse, com fortes bandamento e foliação, e textura hipidiomórfica granular grossa parcialmente recristalizada.

Os resultados analíticos de 11 spots em 9 cristais constam da Tabela 13 e do diagrama da figura $3 f$. Onze spots, pertencentes à mesma população de cristais magmáticos (MSWD $=1,07$ ), formam um aglomerado que se alinha em discórdia com intercepto superior em $2050 \pm 12 \mathrm{Ma}$, interpretado como a idade de cristalização magmática. O spot 9.1 , situado em sobrecrescimento metamórfico externo, caracterizado por alta luminescência em CL (baixo U), apresentou idade ${ }^{206} \mathrm{~Pb} /{ }^{238} \mathrm{U}$ aparente de $565 \pm 23 \mathrm{Ma}(1 \sigma)$, interpretada como a idade de recristalização do embasamento da borda sudeste do Cráton São Francisco durante a Orogênese Brasiliana.

Os dados acima apresentados definem distintos episódios magmáticos/acrescionários paleoproteróicos (rhyacianos), com idades de cristalização entre 2170-2050 $\mathrm{Ma}$. Os gnaisses TTG anteriormente interpretados como arqueanos e/ou paleoproterozóicos (e.g., Figueiredo \& Teixeira 1996 e referências lá citadas) são aqui redefinidos como uma unidade pré- a sincolisional do Cinturão Mineiro (sensu Teixeira et al. 2000). Por conseguinte, o termo "Complexo Piedade" é aqui adotado e estendido para toda a área do Complexo Mantiqueira situada a leste do cráton, para adequação do termo "Gnaisse Piedade" de Ebert (1956) ao Código de Nomenclatura Estratigráfica.

$\mathrm{Na}$ amostra da fase pré-colisional (LC 13A) também foi possível datar dois eventos metamórficos sobrepostos (Tab. 2). O evento $M_{1}(2028 \mathrm{Ma})$ corresponde à fase tardi-colisional do Cinturão Mineiro, e confirma dados de outras unidades (Teixeira et al. 2000). O evento $M_{2}$ se manifesta pela recristalização da borda de cristais de zircão paleoproterozóicos e que data de ca. 565-540 Ma. Esse intervalo tem ampla representação nas regiões sul da Faixa Araçuaí e norte da Faixa Ribeira e se correlaciona com a fase colisional do Orógeno Araçuaí.

A determinação precisa da idade do Complexo Piedade, como apresentada, e sua inserção como parte de arco magmático paleoproterozóico (Figueiredo \& Teixeira 1996) têm profundas implicações para a reconstituição do Cinturão Mineiro. Este cinturão teria se desenvolvido como arco magmático marginal a um núcleo arqueano, compondo a região paleocontinental precursora do Cráton São Francisco.

A fase pré-colisional do arco foi datada em ca. $2170 \mathrm{Ma}$ (amostra LC 13A), enquanto as fases sin- e tardicolisionais em $c a .2100 \mathrm{Ma}$ e $c a .2050 \mathrm{Ma}$ (amostras LC 16, LC $21 \mathrm{e} \mathrm{LC}$ 30). A presença de importante população de núcleos herdados, com idades de ca. $2170 \mathrm{Ma}$, sugere rápida reciclagem dos plutonitos pré-colisionais durante a acresção e colagem orogênica. Idades de acresção das fases pré- e sincolisionais do Cinturão Mineiro semelhantes são descritas em batólitos situados no interior do cráton (e.g. Teixeira et al. 2000) e a amostra LC 26 confirma o limite superior dessa fase.

Em decorrência deste estudo, o Complexo Piedade foi interpretado como raíz de extenso arco magmático, retrabalhado durante as colagens paleo-e neoproterozóicas. Assim, os batólitos do tipo Ritápolis, expostos no interior do cráton (e.g. Teixeira et al.2000), corresponderiam a níveis crustais mais rasos e melhor preservados do arco, apesar do retrabalamento metamórfico em $565 \mathrm{Ma}$ (amostra LC 
26).

\section{CORRELAÇÕES COM O CINTURÃO BAHIA ORIENTAL: O SISTEMA DE ORÓGENOS RHYACIANO $(c a .2170-2040$}

MA) Uma das conseqüêencias mais importantes do presente estudo é a precisa definição geocronológica do Cinturão Mineiro em extesas áreas até então cartografadas como pertencentes ao embasamento arqueano do cráton. Os dados fornecem uma nova dimensão regional ao cinturão e permitem inserí-lo em um amplo sistema de orógenos rhyacianos oriundos da primeira amalgamação pericratônica na borda oriental do cráton. Essa colagem orogênica foi também delieada na borda oriental da cráton na Bahia representada pelo Cinturão Bahia Oriental (Silva et al., nesse volume). O sincronismo entre os eventos pré-colisionais (ca. 2200-2100 Ma) e sincolisonais (ca. 2080-2050 Ma) de ambos cinturões sugere que estes são segmentos de um único sistema de orógenos rhyacianos. Nesse contexto, o Cinturão Mineiro corresponderia a um orógeno acrescionário e o Cinturão Bahia Oriental preservaria o registro de um collision-related orogen (sensu Sengör 1990). Este sistema de orógenos rhyacianos (Leste Sanfranciscano) seria responsável pela amalgamação de diversos blocos continentais evoluídos no Arqueano. $O$ evento $\mathrm{M}_{2}$, que representa a colagem Brasiliana em ca. 570-580 Ma está impresso tanto no Complexo Piedade do Cinturão Mineiro, quanto em outros inliers do embasamento do Orógeno Araçuaí, como os ortognaisses dos complexos Juiz de Fora, Caparaó e Quirino (Söllner et al. 1991, Machado et al. 1996, Valadares et al. 1996).

MAGMATISMO INTRAPLACA INTRUSIVO NOS ORTOGNAISSES ARQUEANOS DO COMPLEXO GUANHÃES: A SUÍTE BORRACHUDOS Granito foliado de Porto Açucena (Suíte Borrachudos) (Amostra LC 40) A Suíte Borrachudos, intrusiva nos ortognaisses do Complexo Guanhães, ocorre em suma faixa de orientação aproximada N-S, por cerca de $200 \mathrm{~km}$, no setor centro-oeste do Orógeno Araçuaí (Fig. 1). A assinatura geoquímica alcalina anorogênica e sua idade de cristalização estateriana foram caracterizadas por Dussin et al. (1993) e Fernandes (2001).

O afloramento amostrado situa-se no Plúton Açucena, ainda não datado. É um granito gnáissico finamente bandado. Ao microscópio, é um hornblenda-biotita sienogranogranito, com quartzo, ortoclásio, albita e biotita, subordinadamente magnetita e fluorita. A textura é recuperada granoblástica alongada fina a média, com forte orientação dos máficos.

Os resultados analíticos de 12 spots em 10 cristais constam da Tabela 14 e do diagrama da figura 4a. Oito spots, pertencentes à mesma população de cristais magmáticos (MSWD $=0.69$ ) e formam um agrupamento concordante com idade ${ }^{207} \mathrm{~Pb} / 200 \mathrm{~Pb}$ média de $1740 \pm 8 \mathrm{Ma}$, interpretada como a idade de cristalização magmática. Idade semelhante é obtida (Fig. 4a) na regressão de 12 spots pertencentes à mesma população de cristais magmáticos (MSWD $=0.73$ ), que formam um agrupamento alinhado segundo uma discórdia com intercepto superior em $1739 \pm 9 \mathrm{Ma}$.

A idade do Plúton Açucena concorda, na faixa do erro, com a do Plúton Morro do Urubu ( $1770 \pm 30 \mathrm{Ma}$, Fernandes 2001), mas esse evento magmático teve longa duração, como demonstra a idade de $1670 \pm 32 \mathrm{Ma}$ do Plúton de Itabira (Chemale Jr. et al. 1998).

\section{FRAGMENTOSDE EMBASAMENTO NA FAIXA ARAÇUAÍ}

Além de extensas áreas de exposição do embasamento nas faixas Araçuaí e Ribeira, como os complexos Juiz de Fora e Piedade, outros remanescentes de unidades préneoproterozóicas retrabalhadas foram escolhidos para o presente estudo, como a seguir detalhados.

\section{Granulito charnockítico de Alto Caparaó (Amostra LC 32)} A amostra pertence à Suíte Caparaó (Söllner et al. 1991) e é um leucocharnockito gnáissico, com foliação de alto ângulo e intercalações de gnaisse máfico. A suíte ocorre como extenso e estreito inler do embasamento tectonicamente intercalado em paragnaisses de alto grau da margem continental do orógeno (Fig. 1). Ao microscópio é um (biotita)orto-piroxênio charnockito gnáissico, com textura recuperada granoblástica alongada, com restos de porfiroclastos lenticularizados de feldspato pertítico magmático. A biotita é rara e provém de retrometamorfismo do ortopiroxênio.

Os resultados analíticos de 22 spots em 21 cristais constam das Tabelas 15 a e $15 \mathrm{~b}$ e dos diagramas das figuras $4 \mathrm{~b}$ e 4c. Os dados são muito complexos e não permitem o seu tratamento conjunto devido ao extremo empobrecimento em U (até $6 \mathrm{ppm}$ ) e Th (até $1 \mathrm{ppm}$ ) dos sobrecrescimentos metamórficos, em contraste com os teores normais nos núcleos magmáticos. Assim, para obter uma idade mais precisa nos sobrecrescimentos utilizou-se a razão $* 206 \mathrm{~Pb} / 238 \mathrm{U}$ obtida no diagrama Concórdia Tera-Wasserburg (Fig. 4c). Nos núcleos, calculou-se a idade por meio das razões ${ }^{207} \mathrm{~Pb} / 206 \mathrm{~Pb}$ em uma Concórdia Wetherill, com correção do $\mathrm{Pb}$ comum a partir de valores medidos de ${ }^{204} \mathrm{~Pb}$ (Fig. 4b).

Nos núcleos, analizou-se 11 spots em 11 cristais (Fig. 4b). Nove spots obtidos de uma mesma população magmática (MSWD $=0,62$ ) se distribuem segundo uma discórdia com intercepto superior em $2195 \pm 15 \mathrm{Ma}$, idade esta interpretada como a de cristalização do magma granítico precursor do gnaisse charnockítico.

Nos sobrecrescimentos metamórficos, analisou-se 11 spots em 10 cristais (Tab. 15b) de uma mesma população (MSWD $=0,89$ ). No diagrama Concórdia Tera-Wasserburg (Fig. 4c), os resultados alinham segundo uma discórdia com intercepto ${ }^{206} \mathrm{~Pb} /{ }^{238} \mathrm{U}$ de $587 \pm 9 \mathrm{Ma}$, interpretado como a idade do pico metamórfico da fácies granulito.

Pelo método U-Pb convencional e emprego de diagrama Concórdia Tera-Wasserburg em amostra de gnaisse desta unidade, Söllner et al. (1991) obtiveram um intercepto superior com idade de $2170 \mathrm{Ma}$. Os autores interpretam a rocha como paragnaisse e a idade obtida como a da área-fonte dos sedimentos. Por outro lado, o intercepto inferior forneceu a idade de $586 \pm 2 \mathrm{Ma}$, interpretada como a do metamorfismo de alto grau. Embora os resultados obtidos pelo método SHRIMP (ca. $2195 \mathrm{Ma}$ e $587 \mathrm{Ma}$ ) sejam equivalentes aos de Söllner et al. (1991), a sua interpretação é distinta e as imagens de catodoluminiscência permitem interpretar o intercepto superior obtido neste trabalho como a idade de cristalização magmática do protólito do gnaisse charnockítico.

Além dos ortognaisses do Caparaó, outros fragmentos de embasamento das faixas Araçuaí e Ribeira, não abordados neste trabalho, apresentam idades de cristalização magmática paleoproterozóica, como o Complexo Juiz de Fora (2130-2200 Ma), com retrabalhamento em ca. $590 \mathrm{Ma}$ (Söllner et al. 1991, 

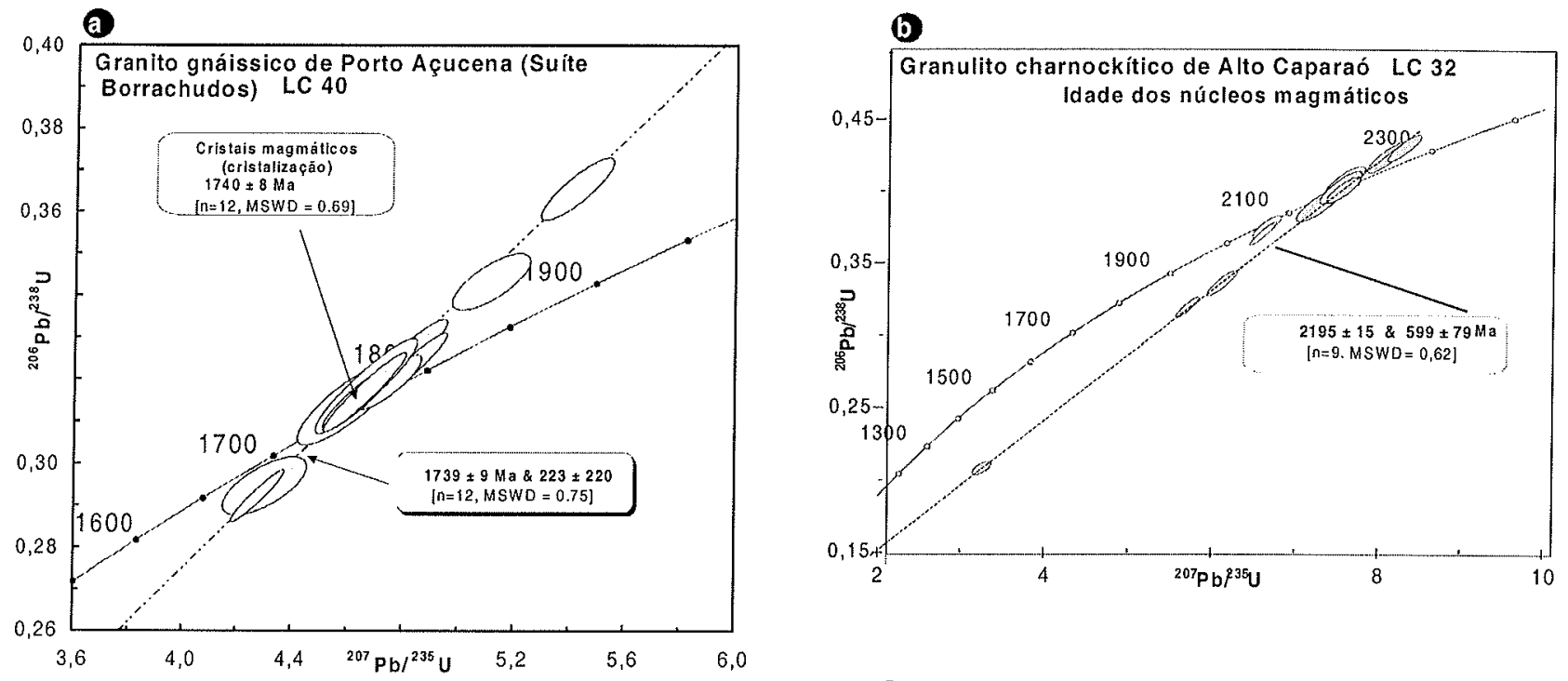

C
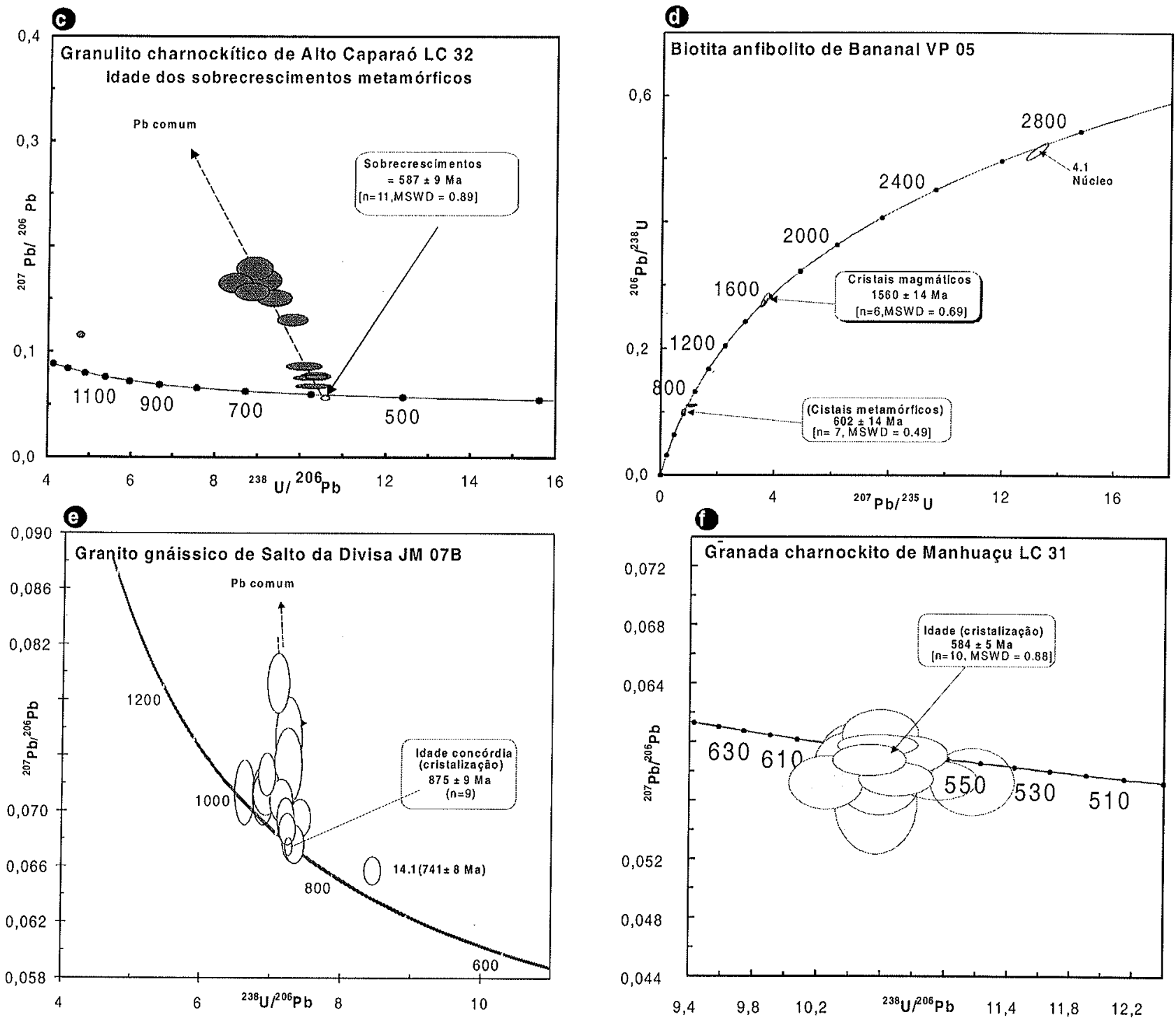

Figura 4 - Diagramas concórdia das amostras: metamórficos); d) VP 05; e) JM 07B; f) LC 31

a) LC40; b) LC 32 b (núcleos magmáticos); c) LC 32 (sobrecrescimentos 
Machado et al. 1996), e o Complexo Quirino de ca.2180 Ma (Machado et al. 1996, Valadares et al. 1996).

\section{Anfibolito Bananal/Complexo Pocrane (Amostra VP 05) O} Complexo Pocrane é outro fragmento de embasamento e situa-se no núcleo do Orógeno Araçuaí (Fig. 1). A amostra foi coletada nas proximidades da localidade de Bananal. Em afloramento, consiste de intercalações de bandas anfibolíticas (amostra) em ortognaisse tonalítico regional. Ao microscópio, é anfibolito de granulação média a fina composto por plagioclásio, hornblenda, biotita e minerais opacos, com forte bandamento composicional submilimétrico.

Os resultados analíticos de 17 spots em 17 cristais constam da Tabela 16 e do diagrama da figura $4 \mathrm{~d}$. Os resultados se agrupam em duas populações, uma das quais constituída de cristais ígneos euédricos, prismáticos e homogêneos, sem distinção entre núcleo e margem. Seis spots dessa população (MSWD $=0,69)$ forneceram idade aparente de $1560 \pm 14$ Ma, interpretada como a de cristalização magmática.

A outra população consiste de cristais prismáticos, ígneos, metamorfizados, alterados e corroídos, com conteúdos muito baixos de U e Th, característicos de metamorfismo de alto grau. Sete spots de uma mesma população $(\mathrm{MSWD}=0.49)$ formam um aglomerado concordante que forneceu idade ${ }^{206} \mathrm{~Pb} /{ }^{238} \mathrm{U}$ aparente de $602 \pm 14 \mathrm{Ma}$, interpretada como a do metamorfismo.

O spot 3.1 apresentou idade ${ }^{207} \mathrm{~Pb} / \mathrm{Pb}^{206}$ aparente de $2715 \pm 15$ Ma (1s), interpretada como de um xenocristal. A idade do xenocristal tem reprodutibilidade regional e indica heranca de crosta da fase pré-colisional do sistema de orógenos rhyacianos na região, isto é, os complexos Juiz de Fora e Quirino. Pode corresponder à idade dos ortognaisses encaixantes dos anfibolitos do Complexo Pocrane, ao qual tem sido atribuída idade arqueana. Estudos geocronológicos adicionais são indispensáveis para testar essas hipóteses.

\section{MAGMATISMO PRÉ-OROGÊNICO DA ABERTURA DO}

RIFT ARAÇUAÍ A época de abertura do rift continental na parte brasileira da bacia Araçuaí-Congo Ocidental tem sido balizada, no intervalo $1000-900 \mathrm{Ma}$, por datações U-Pb (Machado et al. 1989) e Ar-Ar (D'Agrella-Filho et al. 1990) de diques máficos. Idades U-Pb SHRIMP de zircões detríticos de rochas sedimentares glácio-marinhas também sugerem que a sedimentação da fase rift situa-se no intervalo 1000 $900 \mathrm{Ma}$ (Pedrosa-Soares et al. 2000). No lado africano da bacia, o vulcanismo bimodal da fase rift está datado pelo método U-Pb SHRIMP em zircão entre $1000 \mathrm{Ma}$ e $910 \mathrm{Ma}$ (Tack et al. 2001).

Visando datar o evento magmático associado à abertura do rift Araçuaí, selecionou-se o plúton granito-gnáissico Salto da Divisa, devido à sua natureza subalcalina, sugestiva de intrusão em regime distensivo.

Granito-gnaisse subalcalino de Salto da Divisa (Amostra JM 07B) O maciço situa-se no extremo nordeste da Faixa Araçuaí e é intrusivo em ortognaisses migmatíticos paleoproterozóico-arqueanos do embasamento deste orógeno (Fig. 1). Em trabalhos anteriores, a unidade foi cartografada como pertencente ao embasamento do orógeno. Sua composição varia entre monzogranito, sienogranito e alcaligranito. Quimicamente, é uma suíte metaluminosa, subalcalina (cálcio-alcalina de alto $\mathrm{K}$ ), com acentuada tendência alcalina, compatível com granitos tipo LPA (late, postectonic and anorogenic granites). É um granito gnáissico finamente bandado, homogêneo. A amostra datada é um anfibólio (hornblenda?) monzogranito, com textura recuperada granoblástica grossa com domínios hipidiomórficos e, locamente, porfiroclastos de quartzo e feldspato magmáticos.

Os resultados analíticos de 17 spots em 17 cristais constam da Tabela 17 e do diagrama da figura 4e. Nove spots obtidos em cristais ígneos de uma mesma população forneceram idade concórdia (concordia age) ${ }^{206} \mathrm{~Pb} /{ }^{238} \mathrm{U}$.de $875 \pm 9 \mathrm{Ma}$, interpretada como a de cristalização magmática. Três cristais, não mostrados na figura 16, com idades aparentes 2078, 2081 e $1032 \mathrm{Ma} \mathrm{(1s)} \mathrm{são} \mathrm{interpretados} \mathrm{como} \mathrm{xenocristais.}$

A idade toniana e a assinatura subalcalina indicam que $o$ magma precursor do ortognaisse de Salto da Divisa posicionou-se na crosta durante a fase rift da Bacia AraçuaíCongo Ocidental. Trata-se da primeira caracterização de granito anorogênico da fase rift no lado brasileiro do Orógeno Araçuaí-Congo Ocidental.

MAGMATISMO SINCOLISIONAL NO ORÓGENO ARAÇUAí Para datar este evento, selecionou-se três unidades de ortognaisses da borda ocidental do Orógeno Araçuaí, anteriormente cartografadas como parte do embasamento arqueano (amostras LC 38 e LC 39), e paleoproterozóico (amostra LC 31), e um granada-biotita granito (LC 48) (Fig. 1).

Granada gnaisse charnockítico de Manhuaçu (Amostra LC 31) Nos mapas geológicos disponíveis, essa unidade era atribuída ao Complexo Juiz de Fora. Trata-se de um granada gnaisse charnockítico, associado a paragnaisses neoproterozóicos, dos quais deriva por fusão parcial, como se constata local e regionalmente. É uma fase granítica sintectônica, peraluminosa, rica em almandina (charnockito tipo S). Ao microscópio, é um biotita-granada charnockito com textura hipidiomórfica granular parcialmente recristalizada e forte orientação de biotita.

Os resultados analíticos de 12 spots em 12 cristais constam da Tabela 18 e do diagrama da figura 4f. Dez spots datados pertencem à mesma população magmática $(\mathrm{MSWD}=0,88) \mathrm{e}$ formam um aglomerado concordante com idade ${ }^{206} \mathrm{~Pb} /{ }^{238} \mathrm{U}$ de $584 \pm 6 \mathrm{Ma}$, interpretada como a de cristalização magmática. Imagens de catodoluminescência mostram que quase toda a população de zircões ocorre como cristais multifacetados, arredondados, sugestivo de cristalização sob condições de alto grau, mas não apresentam recristalização ou sobrecescimentos metamórficos internos, com preservação das texturas magmáticas originais. Ademais, os altos teores de U e Th são compatíveis com os observados em rochas magmáticas. Essas características indicam que a cristalização magmática foi sintectônica ao pico do metamorfismo regional granulítico, sem retrabalhamento póscristalização, e a idade de $584 \mathrm{Ma}$ é a melhor estimativa para a do pico do evento metamórfico/colisional na região.

Numerosos plútons de granada charnockito associados a granada leucogranito, ambos do tipo $S$, são componentes importantes do estágio sincolisional do arco magmático do Orógeno Araçuaí. Este estágio corresponde à granitogênese $g_{2}$, aqui datada entre 580 e $560 \mathrm{Ma}$ (ver abaixo). Adicionalmente, a idade de $584 \pm 5$ Ma do granada gnaisse charnockítico de Manhuaçu é 
semelhante a outras idades U-Pb e $\mathrm{Pb}-\mathrm{Pb}$ (evaporação de zircão) obtidas para o estágio de granitogênese sincolisional $\mathrm{g}, \mathrm{em}$ outras áreas do Orógeno Araçuaí (Nalini 1997, Silva 1999, Valadares et al. 1999, Noce et al. 2000,).

Biotita gnaisse tonalítico (Governador Valadares I) (Amostra LC 38) A unidade amostrada foi recentemente cartografada como parte do Complexo Mantiqueira (Projeto Leste, CPRM 1999). Consiste de ortognaisse tonalítico homogêneo, finamente bandado, com intercalações métricas a decamétricas de granada-sillimanita paragnaisse parcialmente fundidas e cavalgadas pelos ortognaisses. Ao microscópio, é biotita-tonalito gnáissico, com textura microporfiroclástica, com matriz recuperada granoblásticaalongada e poligonal, com forte orientação da mica. Os porfiroclastos ocorrem como augens de 2-4 mm de comprimento e consistem de quartzo, felsdpato-K e plagioclásio magmáticos.

Os dados analíticos de 8 spots em 8 cristais constam da Tabela 19 e do diagrama da figura 5a. Todos os spots obtidos em zircões ígneos de uma mesma população (MSWD = 0.45 ) forneceram idade ${ }^{206} \mathrm{~Pb} /{ }^{238} \mathrm{Ude} 565 \pm 31 \mathrm{Ma}$, interpretada como a de cristalização magmática. Considerando que os cristais têm um fino ( $5 \mathrm{~mm})$ sobrecrescimento metamorfico externo de alta luminosidade (baixo $\mathrm{U}$ ), é provável que a idade idade obtida seja também a melhor estimativa para o pico do metamorfismo sobreposto. Na mesma concódia, descartando-se dois spots com razões ${ }^{206} \mathrm{~Pb} /{ }^{238} \mathrm{U}$ mais altas, obtem-se um agrupamento com idade concórdia (concordia age) de $553 \pm 8 \mathrm{Ma}$. Embora seja uma idade concórdia, ela não tem reprodutibilidade regional, pois é acentuadamente inferior às menores idades obtidas para a fase sincolisional do cinturão (ca $560 \mathrm{Ma}$ ).

A idade da cristalização sintectônica desse tonalito equivale, dentro do erro do método, à idade de outros plútons sincolisionais do Orógeno Araçuaí (Rio Doce) datados em $560 \mathrm{Ma}$ (Silva 1999, Silva et al. 2002b).

Biotita gnaisse granodiorítico (Governador Valadares II) (Amostra LC 39) Assim como a unidade da amostra anterior (LC 38), este gnaisse foi recentemente cartografado como componente do Compexo Mantiqueira (Projeto Leste, CPRM 1999). É um ortognaisse granodiorítico, homogêneo, finamente bandado, que cavalga o ortognaisse acima descrito. Ao microscópio, é um biotita granodiorito com textura porfiroclástica, matriz granoblástica média com abundantes porfiroclastos subcentimétricos, lenticularizados de ortoclásio microclinizado e plagioclásio magmáticos, subordinadamente biotita titanífera parcialmente cloritizada e orientada.

Os resultados analíticos de 17 spots em 15 cristais constam da Tabela 20 e do diagrama da figura 5 b. Oito spots obtidos em núcleos ou sobrecrescimentos internos ígneos, pertencentes a uma mesma população, forneceram a idade concórdia (concordia age) de $561 \pm 7 \mathrm{Ma}$, interpretada como a idade de cristalização magmática. Alguns cristais apresentam núcleos com textura e forma variadas, alguns arredondados, detríticos, com idades entre ca. $614 \mathrm{Ma}$ (spot 14.2) e ca. $2160 \mathrm{Ma}$. Os núcleos apresentam sobrecrescimento magmático com idade ${ }^{206} \mathrm{~Pb} /{ }^{238} \mathrm{Ude}$ ca. $560 \mathrm{Ma}($ e.g. spots 14.1), e são interpretados como herdados de fontes distin- a

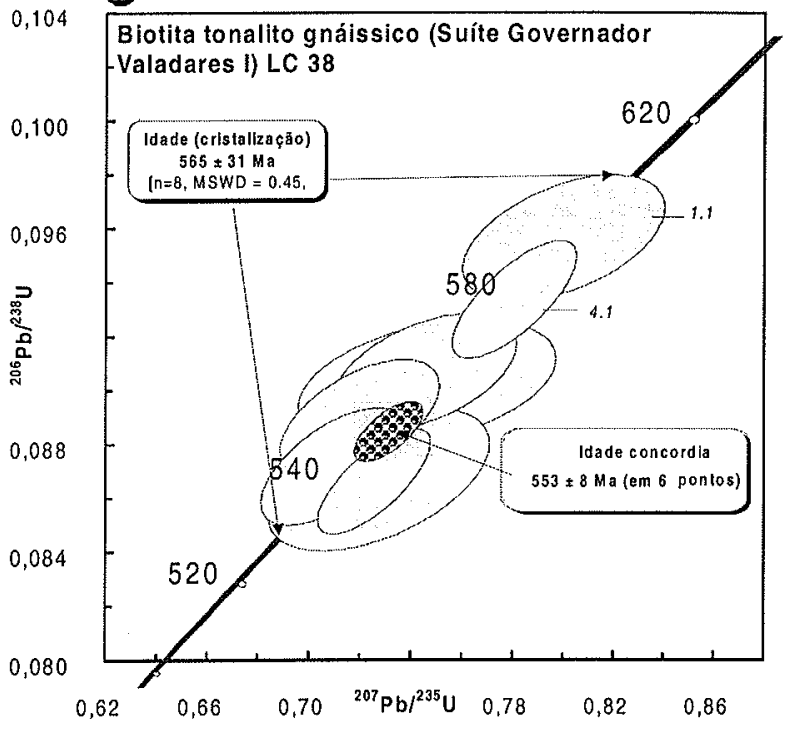

(0)
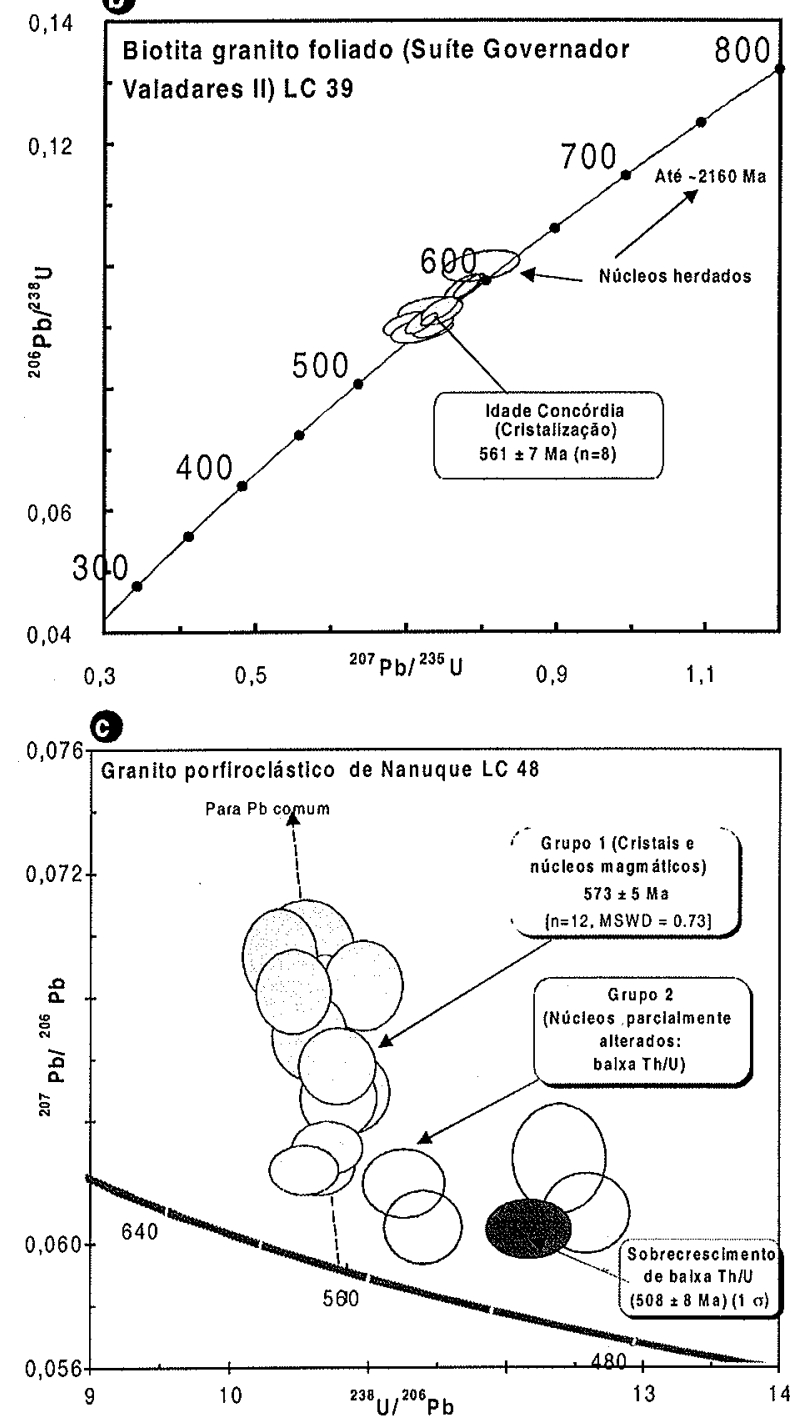

Figura 5 - Diagramas concórdia das amostras: a) LC 38; b) $L C 39$; c) $L C 48$ 
tas. Os sobrecrescimentos magmáticos são, por sua vez, atribuídos à precipitação direta a partir de magmas do tipo $S$ (e.g. Williams 1998).

Assim como na amostra anterior, a idade de cristalização $(561 \pm 7 \mathrm{Ma})$ desse granito resultante de fusão crustal coincide, dentro da incerteza analítica, com as idades de ca. 560 Ma obtidas em corpos sincolisionais $\mathrm{g}_{2}$, como os picos do Pão de Açúcar e do Corcovado, alojados na margem sudeste do Orógeno Araçuaí (Rio Doce). Os dados aqui apresentados reforçam a sugestão de que estes magmas do tipo $S$ se formaram durante fase sincolisional da evolução do arco magmático do orógeno Araçuaí (Rio Doce) entre ca. 580-560 Ma (Silva et al. 2002b, Delgado et al. 2002).

Granada-biotita granito foliado de Nanuque (Amostra LC 48) O magmatismo do tipo $S$, gerador de extenso batólito com rochas contendo granada e cordierita da região de Nanuque, é atribuído à granitogênese sincolisional $\mathrm{g}_{2}$ do Orógeno Araçuaí (Pedrosa-Soares et al. 2001). Estas rochas também foram correlacionadas ao extenso arco magmático continental do sistema orogênico brasiliano III (Araçuaí-Rio Doce), cuja extremidade sudeste estaria representada pelo Arco Rio de Janeiro (granitos g Pão de Açúcar e Corcovado, de ca 560 Ma; Silva, 1999, Silva et al. 2002b).

A amostra é um granito porfirítico, com forte alinhamento de megacristais de feldapato potássico e biotita, os quais fornecem à rocha forte trama planar gnáissica. Ao microscópio, é um granada-biotita granito com textura megaporfirítica com forte orientação, imersos em matriz de granulação média, parcialmente recristalizada.

Os resultados analíticos de 17 spots em 14 cristais constam da Tabela 21 e do diagrama da figura 5c. Dez spots pertencentes à mesma população magmática $(\mathrm{MSWD}=0,73)$ formam um aglomerado discretamente discordante que intercepta a concórdia em $573 \pm 5 \mathrm{Ma}$. Esse resultado é interpretado como a idade de cristalização do magma granítico. Imagens de catodoluminiscência mostram que parte dos cristais magmáticos apresenta discreto sobrecrescimento periférico de baixa luminescência (teores normais de $U$ ). A datação desta fase (spot 3.1) forneceu idade aparente de $508 \pm 8 \mathrm{Ma}(1 \sigma)$, enquanto o nucleo magmático (spot 3.2) de $564 \pm 10 \mathrm{Ma}(1 \sigma)$.

A idade de $573 \pm 5 \mathrm{Ma}$ confirma a cristalização sincolisional deste granito, contrapondo-se à idade de $c a .760 \mathrm{Ma}$ obtida por Celino (1999), em isócrona Sm-Nd. Essa idade confirma a correlação do Batólito Nanuque à Suite Rio de Janeiro datada em $c a .560 \mathrm{Ma}$ e consideradas como parte de extenso arco magmático continental da fase sincolisional $\left(\mathrm{g}^{2}\right)$ do Orógeno Araçuaí (Rio Doce) (Silva et al. 2002). A unidade é também cronocorrelata aos granitóides sincolisionais de Governador Valadares datados neste estudo.

A presença dos sobrecrescimentos marginais não pode ser atribuída a um evento metamórfico. Um desses domínios, datado em $508 \pm 8 \mathrm{Ma}(1 \mathrm{~s})$, deve resultar de distúrbio isotópico pós-cristalização. Isto pode ser possivelmente atribuído à injeção de granito pós-tectônico exposto no afloramento amostrado e que corta a amostra datada. Estas fases tardias, desprovidas de foliação tectônica, são interpretadas como geradas durante o colapso extensional do orógeno, que teria ocorrido no intervalo 520-500 Ma (Pedrosa-Soares et al. 2001).

CONCLUSÕES Os resultados sintetizados na Tabela 2 permitem os seguintes avanços no conhecimento geológico da borda sudeste do Cráton do São Francisco:

1. Identificação e delimitação do embasamento arqueano no Orógeno Araçuaí-Rio Doce e sua extensão no Cráton São Francisco;

2. Descoberta e caracterização das raízes do arco magmático do Cinturão Mineiro (Complexo Piedade), em extensa faixa pericratônica, com idades entre ca. 2170 e $2050 \mathrm{Ma}$;

3. Determinação da idade de cristalização mesoarqueana (ca. 3000 ) e idade metamórfica neoarqueana (2850 Ma) dos gnaisses enderbíticos de Juiz de Fora;

4. Descoberta de uma extensão do magmatismo sincolisional $(560 \mathrm{Ma})$, possivelmente associado às fases tardias do arco précolisional Serra dos Órgãos-Galiléia (ca 590-570 Ma), no núcleo do Orógeno Araçuaí, na borda oeste do arco (granito-gnáissicos de Governador Valadares), em terrenos até então cartografados como embasamento arqueano-paleoproterozóico deste orógeno. 5. Datação em ca. 570 Ma e caracterização do Batólito Nanuque como extensão setentrional do arco sincolisonal Rio de Janeiro (ca. 560-580 Ma), no Orógeno Araçuaí. Isto, juntamente com os granitóides da região de Governdor Valadares, permite a caracterização desse orógeno como integrante do sistema de orógenos brasiliano III (clímax entre ca. 590-560 Ma) e os discrimina de outros orógenos da Faixa Ribeira com clímax há ca. 630 $\mathrm{Ma}$ (orógenos Rio Negro e Paranapiacaba), integrantes do sistema de orógenos brasiliano II.

6. Descoberta de magmatismo básico calyminiano (ca. 1570 Ma), metamorfisado há ca. $600 \mathrm{Ma}$, em fragmento do embasamento arqueano (Complexo Pocrane) do Orógeno Araçuaí;

7. Reconhecimento da natureza ortoderivada paleoproterozóica (ca.2195 Ma) e datação do evento metamóifico sobreposto ( $c a .590 \mathrm{Ma}$ ) em gnaisses charnockíticos de alto grau do embasamento do Orógeno Araçuaí (Suíte Caparaó);

8. Descoberta e datação do plutonismo alcalino relacionado à fase de rifteamento da Bacia Araçuaí (ca. $880 \mathrm{Ma}$ ).

9. As discrepâncias e variações nas idades obtidas no presente estudo indicam que a maior parte das unidades datadas carece de resolução cartográfica adequada e não pode ser correlacionada por grandes distâncias. Conseqüentemente, são indispensáveis novos projetos de cartografia geológica que enfoquem não apenas o registro geológico correto, como também seu posicionamento cronoestratigráfico preciso ao conhecimento mais realístico da evolução geotectônica. A aplicação intensiva da sistemática U-Pb SHRIMP, especialmente aplicada aos terrenos metamórficos de médio e alto grau, deve desempenhar papel crescente nos trabalhos futuros do Serviço Geológico.

Agradecimentos Ao Dr. Luiz Augusto Bizzi, Diretor de Geologia e Recursos Minerais da CPRM pelo indispensável apoio à execução destes estudos, materializados nos artigos que constam deste fascículo. Aos Profs. Fernando Flexa Alkimin e Heinz Dirk Ebert pelas discussão e esclarecimento de diversos aspectos da evolução da área estudada. Aos revisores da RBG pelas sugestões ao manuscrito. 


\section{Referências}

Alkmim F.F., Brito-Neves B.B., Castro-Alves J.A. 1993. Arcabouco tectônico do Cráton do São Francisco. In: J.M.L. Dominguez J.M.L. \& A. Misi (eds.), O Cráton do São Francisco. Salvador, SBG, Núcleo Bahia, 45-62.

Almeida F.F.M, Hasui Y., Brito Neves B.B., Fuck R.A. 1981. Brazilian structural provinces: an introduction. Ear: Sci. Rev., 17:1-29.

Almeida F.F.M. 1977. O Cráton do São Francisco. Rev. Bras. Geoc., 7:349-364

Bizzi L.A., Schobbenhaus C., Baars F.J., Gonçalves J.H., Delgado I.D.M., Abram M.B., Leão Neto R., Matos G.M.M., Santos J.O.S., Silva L.C., Vidotti R.M. 2002. Geologia, Tectônica e Recursos Minerais do Brasil: Sistema de Informações Geográficas - SIG e Mapas na Escala 1:2.500.000. In: L.A. Bizzi, C. Schobbenhaus, R.M. Vidotti, J.H. Gonçalves (eds.) Geologia, Tectônica e Recursos Minerais do Brasil: Texto, Mapas e SIG. 2003. CPRM, Editora da Universidade de Brasília. Brasília.

Carneiro M.A., Teixeira W., Carvalho Júnior I.M, Fernandes R.A. 1998. Sialic crust as a part of the Archean greenstone belt basement, evidence from the Bonfim Metamorphic Complex, Quadrilátero Ferrífero, Brazil. Rev. Bras. Geoc., 28:71-82.

Carneiro M.A. 1992. O Complexo Metamórfico Bonfim Setentrional. (Quadrilátero Ferrifero, Minas Gerais): Litoestratigrafia e Evolução Geológica de um Segmento de Crosta Continental do Arqueano. Inst. de Geociências, Universidade de São Paulo, São Paulo, Tese de Doutoramento, 233p.

Celino J.J., Botelho N.F., Pimentel M.M. 2000. Genesis of Neoproterozoic graniotoid magmatism in the eastern Araçuaí fold belt, esatern Brazil: field, geochemical and Sr-Nd isotopic evidences. Rev. Bras. Geoc., 30:135-139.

Chemale Jr. F., Quade H., Van Schmus W.R. 1998. Petrography, geochemistry and geochronology of the Borrachudo and Santa Bárbara metagranites, Quadrilátero Ferrífero, Brazil. Sbl. Geol. Paläont. Teil I, 3(6):739-750.

D'Agrella-Filho M.S., Pacca I.G., Teixeira W., Onstott T.C., Renne P.R., 1990. Paleomagnetic evidence for the evolution of Meso to Neoproterozoic glaciogenic rocks in central-eastern Brazil. Palaeog. Palaeoclim. Palaeoeco., 80: 255-265.

Delgado I.M., Souza J.D., Silva L.C., Silveira Filho N.C., Santos R.A., Pedreira A.J., Guimarães J.T., Angelim L.A.A., Vasconcelos A.M., Gomes I.P., Lacerda Filho J.V, Valente C.R., Perrotta M.M., Heineck C.A. 2002. Escudo Atlântico, In: Bizzi, L.A., Schobbenhaus, C., Vidotti, M., Gonçalves, J.H. (eds.) Geologia, Tectônica e Recursos Minerais do Brasil. I DVD.

Door II J.V.N. \& Barbosa A.L.M.1963. Geology and ore deposits of the Itabira district. Minas Gerais, Brazil. USGS, Prof. Paper, 341-C, $110 \mathrm{p}$.

Duarte B.P. 1998. Evolução tectônica dos ortognaisses dos Complexos Juiz de Fora e Mantiqueira na região de Juiz de Fora, M.G.: Geologia petrologia e geoquímica. IG USP, São Paulo, Tese de Doutoramento, $280 \mathrm{p}$.

Duarte B.P, Heilbron M., Campos Neto M.C., Porto Jr. R. 1999. The garnet charnockite plutonic body of the Juiz de Fora region, Central segment of the Pan-African/Brasiliano Ribeira Belt, southeastern Brazil. In: SBG, Simpósio Nacional de Estudos tectônicos, 7, Porto Seguro, Resumos Expandidos, Seção 2:56-57.

Dussin I.A., Dussin T.M., Charvet J., Cocherie I.A, Rossi P. 1993. Single zircon dating by stepwise $\mathrm{Pb}$-evaporation of Middle Proterozoic magamatism in the Espinhaço range, SE São Francisco Craton (Minas Gerais, Brazil), In: SBG, Simpósio do Craton São Francisco, 2, Salvador, Anais, 39-42.
Ebert H. 1956. A tectônica do sul do Estado de Minas Gerais e regiões adjacentes. Rio de Janeiro, Diretoria de Geologia e Mineração-DGM. (Relatório Anual do Diretor), pp. 97-107 e 136-137.

Fernandes M.L.S. 2001. O Granito Borrachudos entre Dores de Guanhães e Guanhães: gênese e evolução. Depto. Geologia, UFRJ, Rio de Janeiro. Tese Doutoramento, $172 \mathrm{p}$.

Figueiredo M.C.H. \& Teixeira W. 1996. The Mantiqueira Metamorphic Complex, Eastern Minas Gerais State: preliminary geochronological and geochemical results. An. Acad. Bras. Ciências 68:223-246.

Grossi-Sad J.H., Chiodi Filho C., Santos J.F., Magalhães J.M.M., Carelos P.M. 1990. Geoquímica e origem da formação ferrífera do Grupo Guanhães, Distrito de Guanhães, MG, Brasil. In: SBG, Cong. Bras. Geol., 36, Natal, Anais, 3:1241-1253.

Ludwig K.R. 2001a. Squid 1.02. A user's manual. BGC Special Publ. 2., Berkeley, 19p.

Ludwig K.R. 2001b. User's manual for Isoplot/Ex v. 2.47. A geochronological toolkit for Microsoft Excel. BGC Special Publ. $1 \mathrm{a}$, Berkeley, 55p

Machado N. \& Carneiro M.A. 1992. U-Pb evidence of late Archean tectono-thermal activity in the southern São Francisco shield, Brazil. Can. J. Ear. Sci, 29:2341-2346

Machado N., Schrank A., Abreu F.R., Knauer L.G., Almeida-Abreu P. A. 1989. Resultados preliminares da geocronologia U/Pb na Serra do Espinhaço Meridional. Boletim da SBG-Núcleo Minas Gerais, 10:171-174

Machado N., Valladares C., Heilbron M., Valeriano C. 1996. U-Pb geochronology of the central Ribeira Belt (Brazil) and implications for the evolution of the Brazilian Orogeny. Prec. Res., 79:347-361.

Nalini H.A. 1997. Caractérization des suites magmatiques néoprotérozoïques de la région de Conselheiro Pena et Galiléia, Minas Gerais, Brésil. PhD Thesis, École Nationale Superière des Mines de Saint Etienne, France. 250 p.

Noce C.M., Machado N., Teixeira W. 1998. U-Pb geochronology of gneisses and granitoids in the Quadrilátero Ferrífero (southern São Francisco craton): age constraints for Archean and Paleoproterozoic magmatism and metamorphism. Rev. Bras. Geoc., 28:95-102.

Noce C.M.; Macambira M.B., Pedrosa-Soares A.C. 2000. Chronology of Neoproterozoic-Cambrian granitic magmatism in the Araçuaí Belt, Eastern Brazil, based on single zircon evaporation dating. Rev. Bras. Geoc., 30: 25-29.

Paces J.B. \& Miller J.D. 1989. Precise U-Pb ages of Duluth Complex and related mafic intrusions, northeastern Minnesota: geochronological insights to physical, petrogenic, paleomagnetic and tectonomagmatic processes associated with the 1.1 Ga Midcontinent Rift System. $J$. Geophys. Res., 98B, 13997-14013.

Pedrosa-Soares A.C., Noce C.M., Wiedmann C.M., Pinto C.P. 2001. The Araçuaí-West-Congo Orogen in Brazil: an overview of a confined orogen formed during Gondwanaland assembly. Prec. Res., 110:307323.

Pedrosa-Soares A.C., Dardenne M.A., Hasui Y., Castro F.D.C., Carvalho M.V.A., 1994. Nota Explicativa dos Mapas Geológico, Metalogenético e de Ocorrências Minerais do Estado de Minas Gerais (Escala 1:100.000). Secretaria de Recursos Minerais Hídricos e EnergéticosSEME/Companhia Mineradora de Minas Gerais-COMIG.

Sengör A.M.C. 1990. Plate tectonics and orogenic research after 25 years: synopsis of a Thetyan perspective. Ear. Sci. Rev. 27:1-201.

Silva L.C. 1999. Geocronologia U-Pb SHRIMP e Sm-Nd na Provincia Mantiqueira meridional, no Cinturão Saldania (África do Sul) e a evolução do Ciclo Brasiliano/Pan-Africano. Universidade Federal 
do Rio Grande do Sul-UFRGS, Porto Alegre, Tese de Doutorado, 243p.

Silva L.C., Leite C.A., Heineck C.A., Vieira V.S., Silva M.A., Baars F.J., Perrotta M., Salvador E.D., Lopes R.C., Silva M.G.M., Valente C.R., Lacerda Filho J.V., Drummond J.B.V. 2002a.. Mapa Geológico de Minas Gerais, E: 1.1.000.000. CPRM- Serviço Geológico do Brasil/ COMIG - Companhia Mineradora de Minas Gerais. Belo Horizonte (Inédito).

Silva L.C., Hartmann L.A., McNaughton N.J.L.A., Fletcher I.R. 2002b. The Neoproterozoic Mantiqueira Province and its African connections: a zircon-based U-Pb geochronologic subdivision for the Basiliano/Pan-African systems of orogens. Prec. Res. (submetido).

Söllner F., Lammerer B., Weber-Diffenback K. 1991. Die krustenentwiclkung nordlich von Rio de Janeiro/Brasilien. Munchner Geologische Heft 4, München, 100 p.

Teixeira W., Cordani U.G., Nutman A.P., Sato K. 1998. Polyphase Archean evolution in the Campo Belo metamorphic complex, Southern São Francisco Craton, Brazil: SHRIMP U-Pb zircon evidence. $J$. Sou. Am. Ear. Sci., 11:279-289.

Teixeira W., Sabaté J.P., Barbosa J., Noce C.M., Carneiro A.M. 2000. Archean and Paleoproterozoi tectonic evolution of the São Francisco Craton. In: U. Cordani, E. Milani, A. Thomaz Filho, D.A. Campos

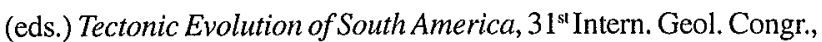
Rio de Janeiro, p. 101-138.

Tuck L., Wingate M.T.D., Liégeos J.P., Fernadez-Alonso M., Deblond A. 2001. Early Neoproterozoic magmatism (1000-910 Ma) of the Zadinian and Mayumbian groups (Bas Congo): onset of Rodinia rifting at the west edge of the Congo Craton. Prec. Res., 110:277. 306.

Valladares C.S, Machado N., Heilbron M., Tupinambá M, Duarte B., Gauthier G., Noronha M. 1999. Ages of detrital zircon from central Ribeira Belt (Brazil) using Laser-ablation-ICPMS. In: South-Am. Symp. Isotope Geol., 2, Córdoba, Argentina, 1999. Acta. Córdoba, SEGEMAR (Serv. Geológico Minero Argentino). v.34, p. 145-147.

William I.S. 1998. U-Th-Pb geocronology by ion Microprobe. In: M.A. McKibben, W.C. Shanks, W.C. Sahnks III, W.I. Ridley (eds.). Applications of microanalytical techniques to understanding mineralising processes. Rev. Econ. Geol., 7:1-35.

Manuscrito A-1333

Recebido em 15 de março de 2002

Revisão dos autores em 20 de dezembro de 2002 Revisão aceita em 23 de dezembro de 2002 